\title{
LEVEL II SCOUR ANALYSIS FOR BRIDGE 16 (BRNATH00800016) on TOWN HIGHWAY 80, crossing LOCUST CREEK, BARNARD, VERMONT
}

U.S. Geological Survey Open-File Report 96-383

Prepared in cooperation with

VERMONT AGENCY OF TRANSPORTATION and

FEDERAL HIGHWAY ADMINISTRATION 


\section{LEVEL II SCOUR ANALYSIS FOR BRIDGE 16 (BRNATH00800016) on TOWN HIGHWAY 80, crossing LOCUST CREEK, BARNARD, VERMONT}

By MICHAEL A. IVANOFF and MATTHEW A. WEBER

U.S. Geological Survey Open-File Report 96-383

Prepared in cooperation with

VERMONT AGENCY OF TRANSPORTATION and

FEDERAL HIGHWAY ADMINISTRATION 


\title{
U.S. DEPARTMENT OF THE INTERIOR BRUCE BABBITT, Secretary
}

\author{
U.S. GEOLOGICAL SURVEY \\ Gordon P. Eaton, Director
}

For additional information write to:

District Chief

U.S. Geological Survey 361 Commerce Way

Pembroke, NH 03275-3718
Copies of this report may be purchased from:

U.S. Geological Survey Earth Science Information Center Open-File Reports Section Box 25286, MS 517 Federal Center

Denver, CO 80225 


\section{CONTENTS}

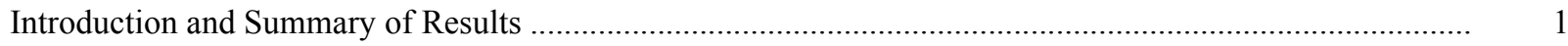

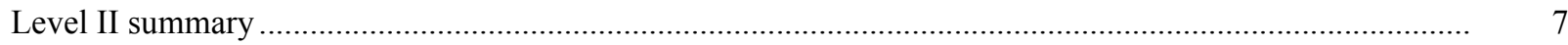

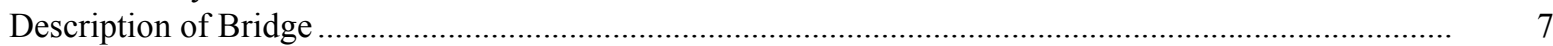

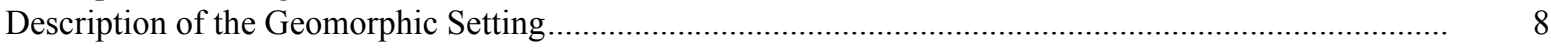

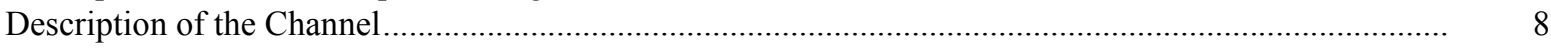

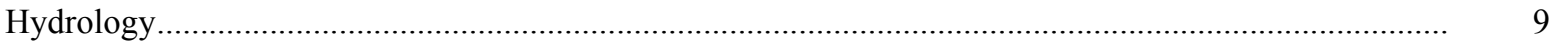

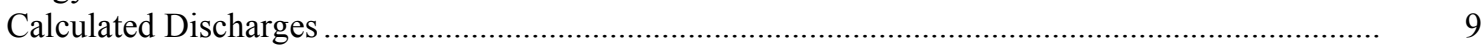

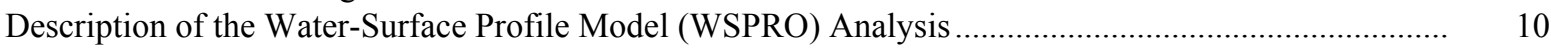

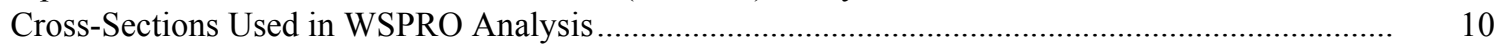

Data and Assumptions Used in WSPRO Model ...................................................................... 11

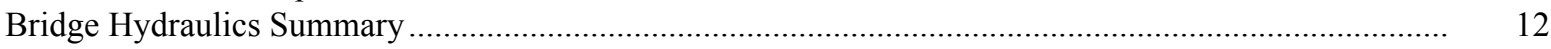

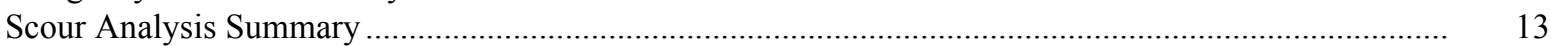

Special Conditions or Assumptions Made in Scour Analysis ...................................................... 13

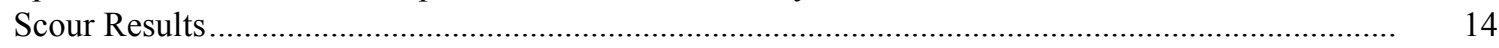

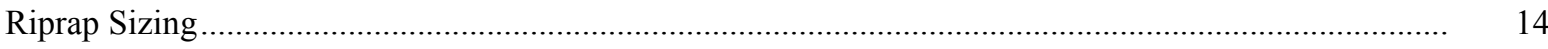

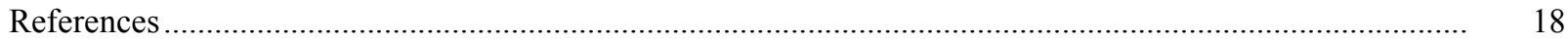

Appendixes:

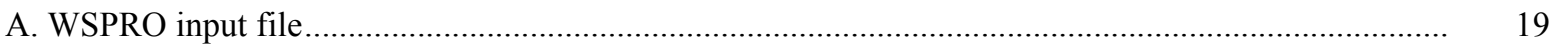

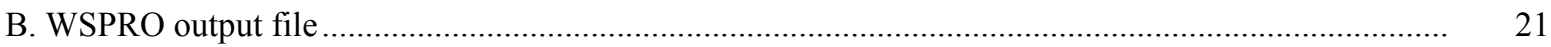

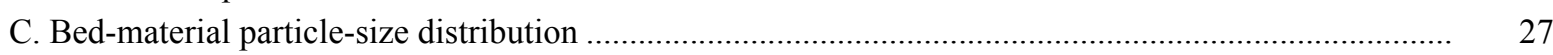

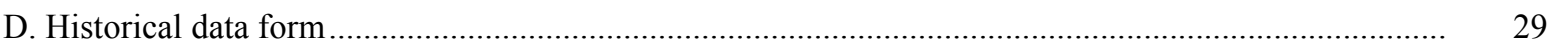

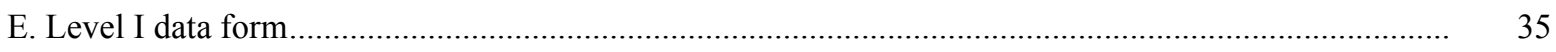

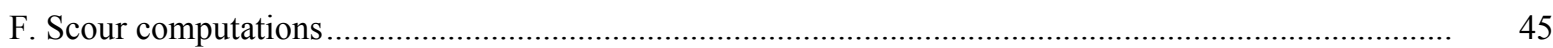

\section{FIGURES}

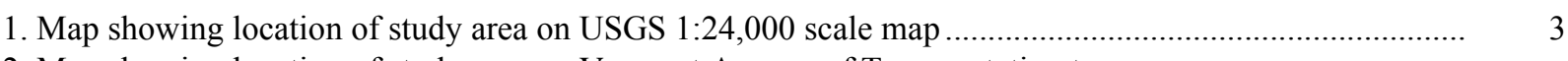

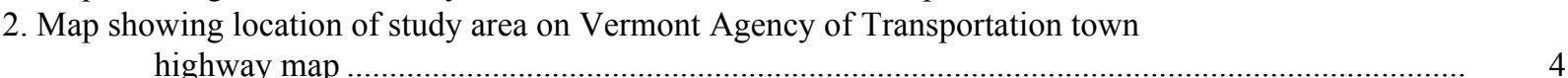

3. Structure BRNATH00800016 viewed from upstream (October 12, 1994) ............................................ 5

4. Downstream channel viewed from structure BRNATH00800016 (October 12, 1994). .......................... 5

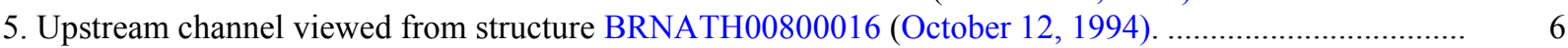

6. Structure BRNATH00800016 viewed from downstream (October 12, 1994)..................................... 6

7. Water-surface profiles for the 100- and 500-year discharges at structure
BRNATH00800016 on Town Highway 80, crossing Locust Creek, Barnard, Vermont.................

8. Scour elevations for the 100-year discharge at structure

BRNATH00800016 on Town Highway 80, crossing Locust Creek, Barnard, Vermont.............. 16

\section{TABLES}

1. Remaining footing/pile depth at abutments for the 100-year discharge at structure BRNATH00800016 on Town Highway 80, crossing Locust Creek, Barnard, Vermont ................. 17

2. Remaining footing/pile depth at abutments for the 500-year discharge at structure BRNATH00800016 on Town Highway 80, crossing Locust Creek, Barnard, Vermont 


\begin{tabular}{|c|c|c|}
\hline Multiply & By & To obtain \\
\hline \multicolumn{3}{|c|}{ Length } \\
\hline inch (in.) & 25.4 & millimeter (mm) \\
\hline foot $(\mathrm{ft})$ & 0.3048 & meter $(\mathrm{m})$ \\
\hline mile (mi) & 1.609 & kilometer (km) \\
\hline \multicolumn{3}{|c|}{ Slope } \\
\hline foot per mile ( $\mathrm{ft} / \mathrm{mi})$ & 0.1894 & meter per kilometer $(\mathrm{m} / \mathrm{km})$ \\
\hline \multicolumn{3}{|c|}{ Area } \\
\hline square mile $\left(\mathrm{mi}^{2}\right)$ & 2.590 & square kilometer $\left(\mathrm{km}^{2}\right)$ \\
\hline \multicolumn{3}{|c|}{ Volume } \\
\hline cubic foot $\left(\mathrm{ft}^{3}\right)$ & $\begin{array}{l}0.02832 \\
\text { Velocity and Flow }\end{array}$ & cubic meter $\left(\mathrm{m}^{3}\right)$ \\
\hline foot per second (ft/s) & 0.3048 & meter per second $(\mathrm{m} / \mathrm{s})$ \\
\hline cubic foot per second $\left(\mathrm{ft}^{3} / \mathrm{s}\right)$ & 0.02832 & cubic meter per second $\left(\mathrm{m}^{3} / \mathrm{s}\right)$ \\
\hline $\begin{array}{l}\text { cubic foot per second per } \\
\text { square mile } \\
{\left[\left(\mathrm{ft}^{3} / \mathrm{s}\right) / \mathrm{mi}^{2}\right]}\end{array}$ & 0.01093 & $\begin{array}{l}\text { cubic meter per } \\
\text { second per square } \\
\text { kilometer }\left[\left(\mathrm{m}^{3} / \mathrm{s}\right) / \mathrm{km}^{2}\right]\end{array}$ \\
\hline
\end{tabular}

OTHER ABBREVIATIONS

$\begin{array}{lrlr}\mathrm{BF} & \text { bank full } & \text { LWW } & \text { left wingwall } \\ \mathrm{cfs} & \text { cubic feet per second } & \text { MC } & \text { main channel } \\ \mathrm{D}_{50} & \text { median diameter of bed material } & \text { RAB } & \text { right abutment } \\ \mathrm{DS} & \text { downstream } & \text { RABUT } & \text { face of right abutment } \\ \mathrm{elev} & \text { elevation } & \text { RB } & \text { right bank } \\ \mathrm{f} / \mathrm{p} & \text { flood plain } & \text { ROB } & \text { right overbank } \\ \mathrm{ft} & \text { square feet } & \text { RWW } & \text { right wingwall } \\ \mathrm{ft} / \mathrm{ft} & \text { feet per foot } & \text { TH } & \text { town highway } \\ \mathrm{JCT} & \text { junction } & \text { UB } & \text { under bridge } \\ \mathrm{LAB} & \text { left abutment } & \text { US } & \text { upstream } \\ \mathrm{LABUT} & \text { face of left abutment } & \text { USGS } & \text { United States Geological Survey } \\ \text { LB } & \text { left bank } & \text { VTAOT Vermont Agency of Transportation } \\ \text { LOB } & \text { left overbank } & \text { WSPRO } & \text { water-surface profile model }\end{array}$

In this report, the words "right" and "left" refer to directions that would be reported by an observer facing downstream. Sea level: In this report, "sea level" refers to the National Geodetic Vertical Datum of 1929-- a geodetic datum derived from a general adjustment of the first-order level nets of the United States and Canada, formerly called Sea Level Datum of 1929.

In the appendices, the above abbreviations may be combined. For example, USLB would represent upstream left bank. 


\title{
LEVEL II SCOUR ANALYSIS FOR BRIDGE 16 (BRNATH00800016) ON TOWN HIGHWAY 80, CROSSING LOCUST CREEK, BARNARD, VERMONT
}

\author{
By Michael A. Ivanoff and Matthew A. Weber
}

\section{INTRODUCTION AND SUMMARY OF RESULTS}

This report provides the results of a detailed Level II analysis of scour potential at structure BRNATH00800016 on town highway 80 crossing Locust Creek, Barnard, Vermont (figures 1-8). A Level II study is a basic engineering analysis of the site, including a quantitative analysis of stream stability and scour (U.S. Department of Transportation, 1993). A Level I study is included in Appendix E of this report. A Level I study provides a qualitative geomorphic characterization of the study site. Information on the bridge, gleaned from Vermont Agency of Transportation (VTAOT) files, was compiled prior to conducting Level I and Level II analyses and can be found in Appendix D.

The site is in the Green Mountain physiographic province of central Vermont in the town of Barnard. The 22.0- $\mathrm{mi}^{2}$ drainage area is in a predominantly rural and forested basin. In the vicinity of the study site, the left banks are forested and the right banks are covered with shrub and brush. Vermont Route 12 is adjacent to the right bank.

In the study area, Locust Creek has an incised channel with a slope of approximately 0.02 $\mathrm{ft} / \mathrm{ft}$, an average channel top width of $60 \mathrm{ft}$ and an average channel depth of $4 \mathrm{ft}$. The predominant channel bed materials are gravel and cobble with a median grain size $\left(\mathrm{D}_{50}\right)$ of $102 \mathrm{~mm}(0.336 \mathrm{ft})$. The geomorphic assessment at the time of the Level I and Level II site visits on September 22, 1994 and October 12, 1994, indicated that the reach was stable.

The town highway 80 crossing of Locust Creek is a 36-ft-long, one-lane bridge consisting of one 33-foot steel-beam span with timber deck (Vermont Agency of Transportation, written communication, August 23, 1994). The bridge is supported by vertical, log crib abutments with wingwalls. Type-2 stone fill (less than 36 inches diameter) protects the upstream and downstream left wingwalls and the downstream left road embankment. Type3 stone fill (less than 48 inches diameter) protects the upstream and downstream right wingwalls. The upstream left and downstream right road embankments are not protected and road wash is eroding these areas. The channel approach to the bridge is straight with the bridge skewed zero degrees to flow; the opening-skew-to-roadway is also zero degrees. Additional details describing conditions at the site are included in the Level II Summary, Appendix D, and Appendix E. 
Scour depths and rock rip-rap sizes were computed using the general guidelines described in Hydraulic Engineering Circular 18 (Richardson and others, 1993). Total scour at a highway crossing is comprised of three components: 1) long-term streambed degradation; 2) contraction scour (due to accelerated flow caused by a reduction in flow area at a bridge) and; 3) local scour (caused by accelerated flow around piers and abutments). Total scour is the sum of the three components. Equations are available to compute depths for contraction and local scour and a summary of the results of these computations follows.

Contraction scour for all modelled flows ranged from 0.0 to $3.7 \mathrm{ft}$. The worst-case contraction scour occurred at the incipient-overtopping discharge, which was between the 100- and 500-year discharge. Abutment scour ranged from 17.5 to $23.2 \mathrm{ft}$. The worst-case abutment scour occurred at the 500-year discharge. Additional information on scour depths and depths to armoring are included in the section titled "Scour Results". Scouredstreambed elevations, based on the calculated scour depths, are presented in tables 1 and 2. A cross-section of the scour computed at the bridge is presented in figure 8. Scour depths were calculated assuming an infinite depth of erosive material and a homogeneous particlesize distribution.

It is generally accepted that the Froehlich equation (abutment scour) gives "excessively conservative estimates of scour depths" (Richardson and others, 1993, p. 48). Usually, computed scour depths are evaluated in combination with other information including (but not limited to) historical performance during flood events, the geomorphic stability assessment, existing scour protection measures, and the results of the hydraulic analyses. Therefore, scour depths adopted by VTAOT may differ from the computed values documented herein. 


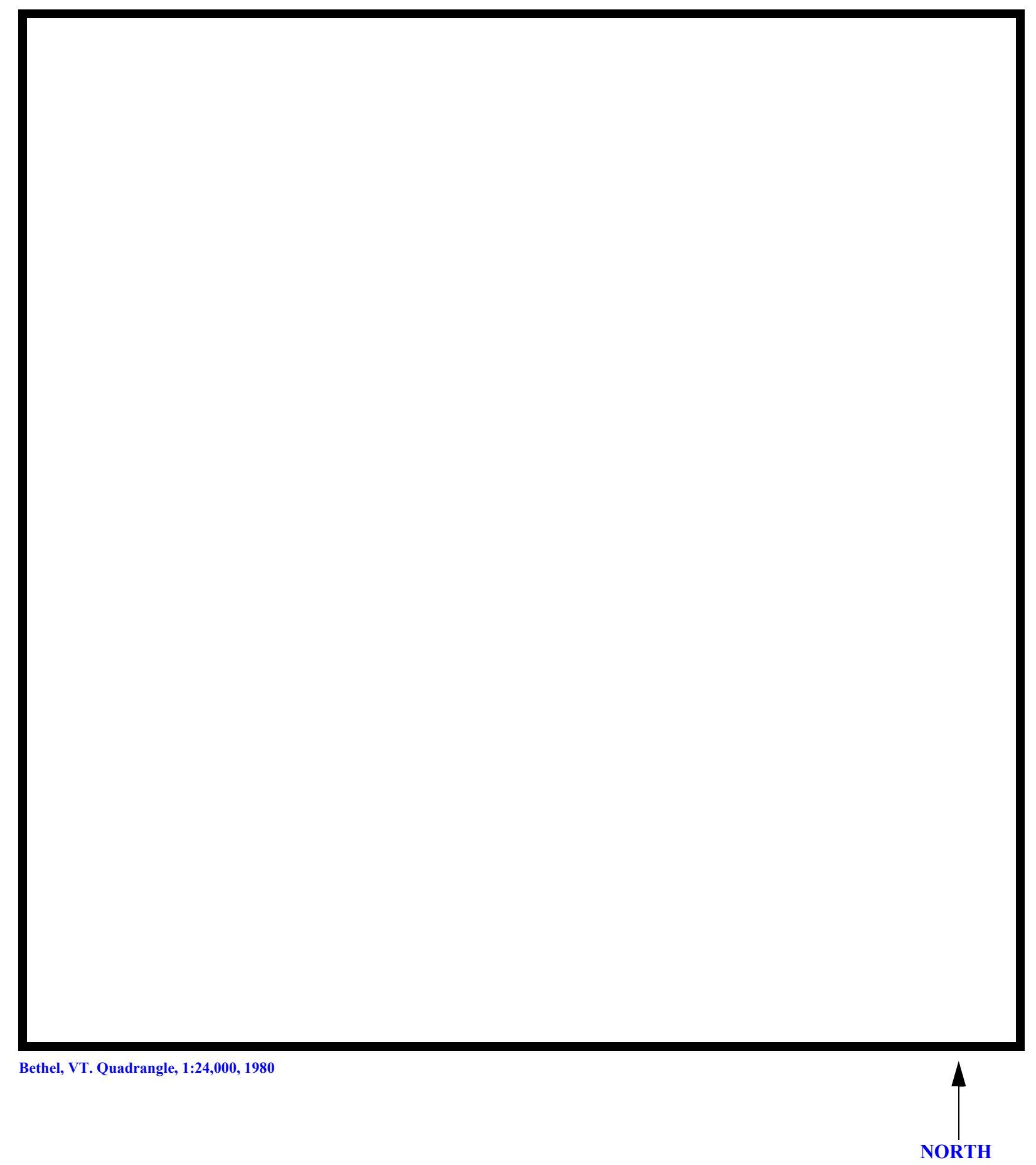

Figure 1. Location of study area on USGS 1:24,000 scale map. 
Figure 2. Location of study area on Vermont Agency of Transportation town highway map. 

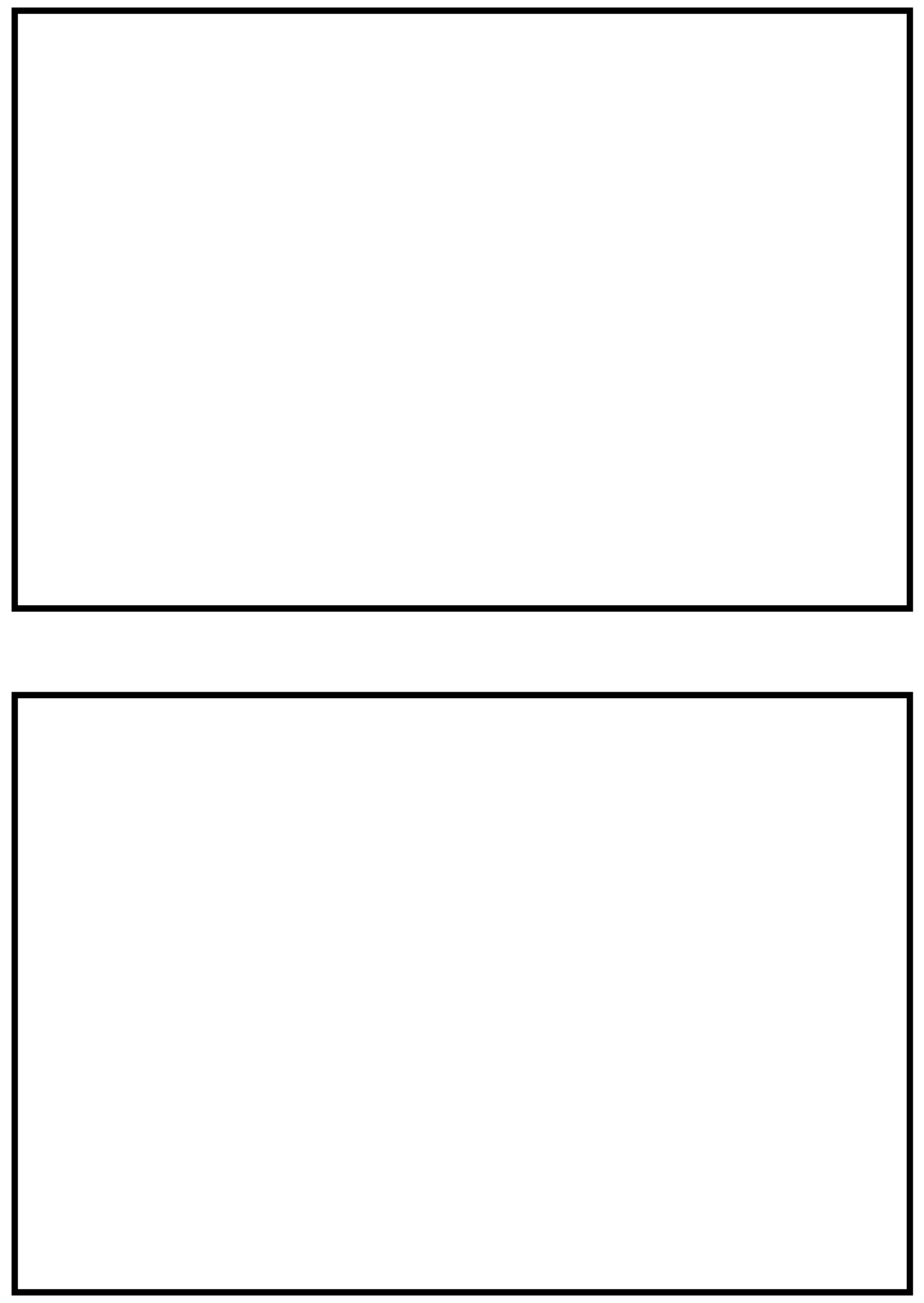

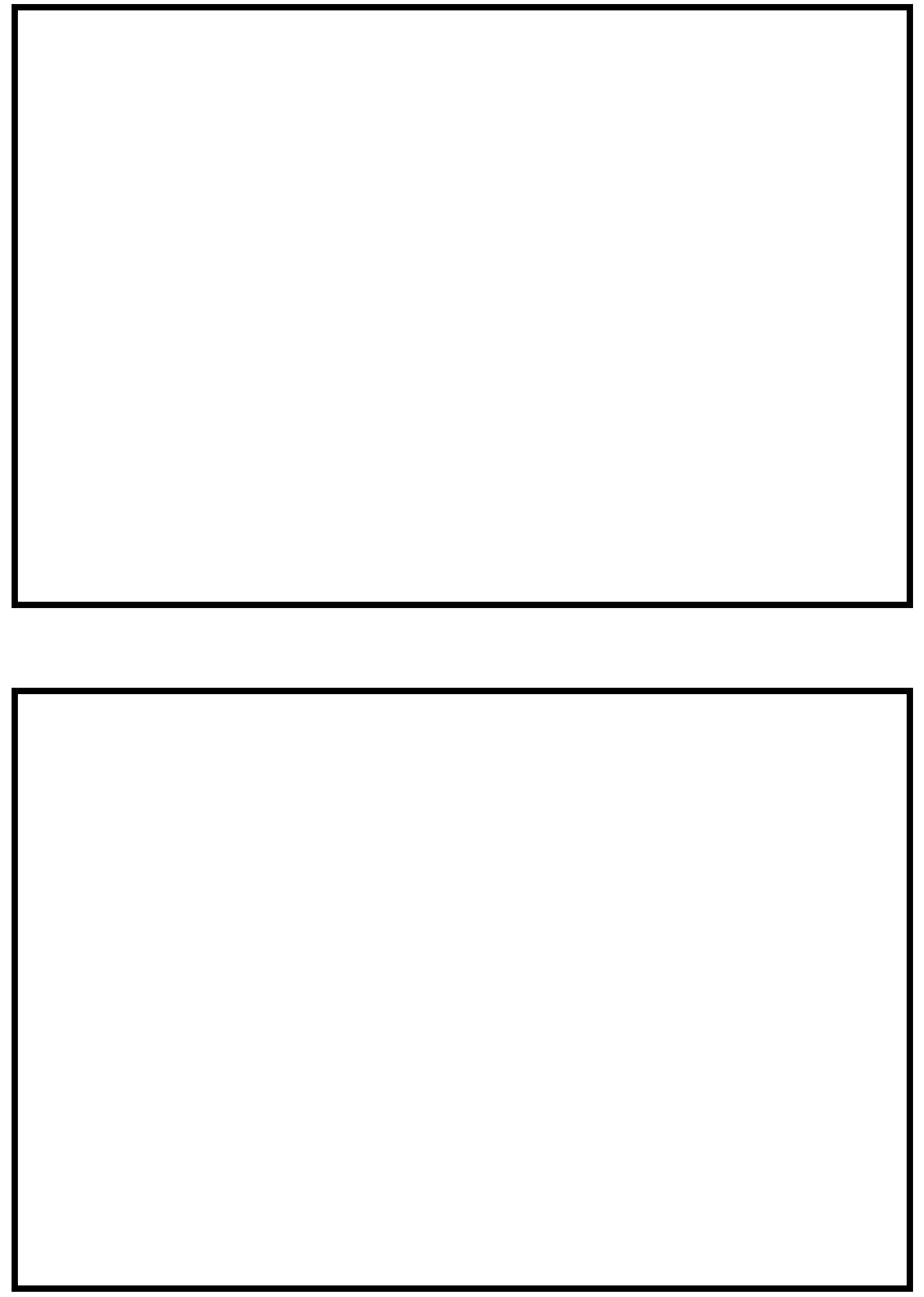


\section{LEVEL II SUMMARY}

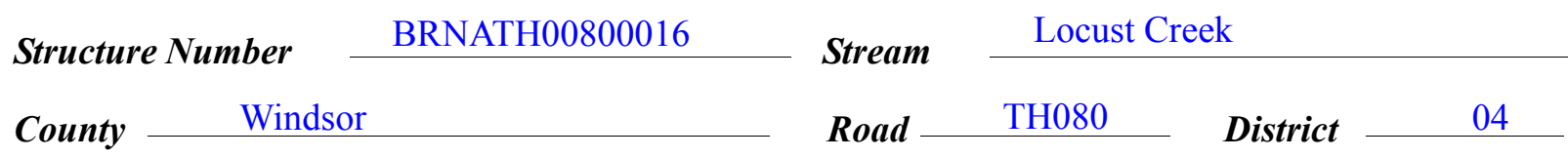

\section{Description of Bridge}

Bridge length $\frac{36}{2 t}$ Bridge width $\quad$ ft Max span length $\stackrel{33}{f t}$ Alignment of bridge to road (on curve or straight) vertical Abutment type

Stone fill on abutment?

\section{Embankment type} straight

sloping

\section{Dato af incnortion} Type-2 exists on the downstream left road approach and the upstream nasanintinu af atnen fill and downstream left wingwalls. Type-3 exists on upstream and downstream right wingwalls.

Abutments and wingwalls consist of log cribbing

$\mathrm{N}$

\section{0}

Is bridge skewed to flood flow according to 'survey? Angle

Debris accumulation on bridge at time of Level I or Level II site visit:

\begin{tabular}{|c|c|c|c|}
\hline & $\begin{array}{c}\text { Date of insnortion } \\
\underline{0}\end{array}$ & $\begin{array}{l}\text { Percent of alommal } \\
\text { blocked inorizontatly }\end{array}$ & $\begin{array}{l}\text { Percent of } 10 / 12 / 10 \\
\text { blocked verticatty }\end{array}$ \\
\hline el & 94 & - & - \\
\hline & Low & & \\
\hline
\end{tabular}

\section{Potential for debris}

None evident on 9/22/94 or 10/12/94.

Dosriho anv, fonturos noar ar at tho hridoo that mav affort flow, (includo ahsorvation dato) 


\section{Description of the Geomorphic Setting}

General topography The bridge is over a steep upland incised channel.

Geomorphic conditions at bridge site: downstream (DS), upstream (US)

Date of inspection $\quad 09 / 22 / 94$

DS left: $\quad$ terrace to valley wall

DS right: $\quad$ terrace to valley wall

US left: $\quad$ terrace to valley wall

US right: terrace to valley wall

\section{Description of the Channel}

\begin{tabular}{|c|c|c|c|}
\hline \multirow[b]{2}{*}{ Average top width } & & \multirow[b]{2}{*}{ Average depth } & \multirow[b]{2}{*}{ sand to boulders } \\
\hline & gravel and cobbles & & \\
\hline Predominant bed material & & Bank material & Narrow, incised \\
\hline channel with only slight sinuosity. & $=\cdots$ & .. & \\
\hline
\end{tabular}

$09 / 22 / 94$

Vegetative col forested with residence on the terrace

DS left: $\quad$ shrub and brush with state route 12 and residence on the terrace

DS right: forested with residence on the terrace

US left: $\quad$ shrub and brush with state route 12 and residence on the terrace

US right: $\quad \underline{\mathrm{Y}}$

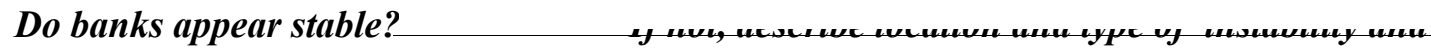

date of observatton.

None evident on

$09 / 22,10 / 12$, or 12/15 1994 respectively.

Describe any obstructions in channel and date of observation. 


\title{
Hydrology
}

Drainage area $\quad 22.0 \quad \mathrm{mi}^{2}$

Percentage of drainage area in physiographic provinces: (approximate)

Physiographic province

Green Mountain
Percent of drainage area

100

\begin{abstract}
Is drainage area considered rural or urban?
Rural urbanization: None.

Describe any significant
\end{abstract}

Is there a USGS gage on the stream of interest?

USGS gage description

USGS gage number

Gage drainage area

$m i^{2}$

No

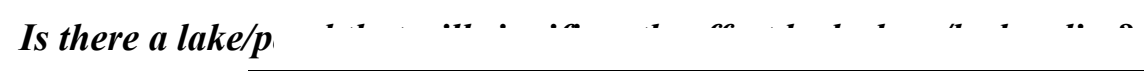

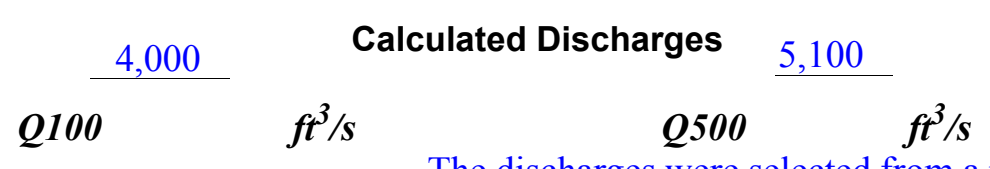

The discharges were selected from a range of values

determined from empirical methods applicable to sites having basin characteristics similar to this one (Talbot, 1887; Potter, 1957a; Potter, 1957b; Benson, 1962; Johnson and Laraway, 1971, written commuication; Johnson and Tasker, 1974; Federal Highway Administration, 1983). 


\section{Description of the Water-Surface Profile Model (WSPRO) Analysis}

Datum for WSPRO analysis (USGS survey, sea level, VTAOT plans)

USGS survey

Datum tie between USGS survey and VTAOT plans $\quad$ Not applicable.

Description of reference marks used to determine USGS datum. $\quad$ RM1 is the top center

of a concrete post marked "VT 1959 DS 035 12/ VT 1956 S 142 2" (elev. 507.24 feet,

arbitrary datum). RM2 is a chiseled square on the top of a boulder, 10 feet streamward

of Rt. 12, 42 feet upstream of the bridge, near top of the right bank (elev. 500.29 feet, arbitrary datum).

\section{Cross-Sections Used in WSPRO Analysis}

\begin{tabular}{|c|c|c|c|}
\hline${ }^{1}$ Cross-section & $\begin{array}{c}\text { Section } \\
\text { Reference } \\
\text { Distance } \\
\text { (SRD) in feet }\end{array}$ & $\begin{array}{c}{ }^{2} \text { Cross-section } \\
\text { development }\end{array}$ & Comments \\
\hline EXIT- & -44 & 1 & Exit section \\
\hline FULLV & 0 & 2 & $\begin{array}{l}\text { Downstream Full-valley } \\
\text { section (Templated from } \\
\text { EXIT-) }\end{array}$ \\
\hline BRIDG & 0 & 1 & Bridge section \\
\hline RDWAY & 10 & 1 & Road Grade section \\
\hline APPRO & 63 & 2 & $\begin{array}{l}\text { Modelled Approach sec- } \\
\text { tion (Templated from } \\
\text { ATEMP) }\end{array}$ \\
\hline ATEMP & 77 & 1 & $\begin{array}{l}\text { Approach section as sur- } \\
\text { veyed (Used as a tem- } \\
\text { plate) }\end{array}$ \\
\hline
\end{tabular}

${ }^{1}$ For location of cross-sections see plan-view sketch included with Level I field form, Appendix E. For more detail on how cross-sections were developed see WSPRO input file. 


\section{Data and Assumptions Used in WSPRO Model}

Hydraulic analyses of the reach were done by use of the Federal Highway Administration's WSPRO step-backwater computer program (Shearman and others, 1986, and Shearman, 1990). The analyses reported herein reflect conditions existing at the site at the time of the study. Furthermore, in the development of the model it was necessary to assume no accumulation of debris or ice at the site. Results of the hydraulic model are presented in the Bridge Hydraulic Summary, Appendix B, and figure 7.

Channel roughness factors (Manning's “ $n$ ”) used in the hydraulic model were estimated using field inspections at each cross section following the general guidelines described by Arcement and Schneider (1989). Final adjustments to the values were made during the modelling of the reach. Channel " $n$ " values for the reach ranged from 0.055 to 0.060 .

Normal depth at the exit section (EXIT-) was assumed as the starting water surface. This depth was computed by use of the slope-conveyance method outlined in the user's manual for WSPRO (Shearman, 1990). The slope used was $0.012 \mathrm{ft} / \mathrm{ft}$ which was estimated from the topographic map (U.S. Geological Survey, 1980).

The surveyed approach section (ATEMP) was moved along the approach channel slope $(0.033 \mathrm{ft} / \mathrm{ft})$ to establish the modelled approach section (APPRO), one bridge length upstream of the upstream face as recommended by Shearman and others (1986). This approach also provides a consistent method for determining scour variables.

For the 100-year and incipient-overtopping discharge, WSPRO assumes critical depth at the bridge section. Supercritical models were developed for these discharges. Analyzing both the supercritical and subcritical profiles for each discharge, it can be determined that the water surface profile does pass through critical depth within the bridge opening. Thus, the assumptions of critical depth at the bridge are satisfactory solutions. 


\section{Bridge Hydraulics Summary}

$\begin{array}{llll}\text { Average bridge embankment elevation } & 498.2 & f t \\ & \text { Average low steel elevation } & 496.6 & \boldsymbol{f t}\end{array}$

100-year discharge $\quad 4,000 \quad \boldsymbol{f t}^{3} / \mathrm{s}$

Water-surface elevation in bridge opening $\quad 489.9 \quad \boldsymbol{f t}$

Road overtopping? ___ N Discharge over road $-{ }_{-}, \mathrm{s}$

Area of flow in bridge opening $\quad 243 \quad \mathrm{ft}^{2}$

Average velocity in bridge opening $16.5 \mathrm{ft} / \mathrm{s}$

Maximum WSPRO tube velocity at bridge $\quad 20.8 \mathrm{ft} / \mathrm{s}$

Water-surface elevation at Approach section with bridge

495.3

Water-surface elevation at Approach section without bridge

490.8

Amount of backwater caused by bridge

$4.5-i$

500-year discharge $\quad 5,100 \quad \mathrm{ft}^{3} / \mathrm{s}$

Water-surface elevation in bridge opening

$496.8 f \boldsymbol{f t}$

Road overtopping? ___ Y Discharge over road $215, \ldots$

Area of flow in bridge opening $\quad 439 \quad \boldsymbol{f t}^{2}$

Average velocity in bridge opening $\quad 11.1 \mathrm{ft} / \mathrm{s}$

Maximum WSPRO tube velocity at bridge 13.8 _s

Water-surface elevation at Approach section with bridge

499.3

Water-surface elevation at Approach section without bridge

Amount of backwater caused by bridge 7.5 .

Incipient overtopping discharge _4,800 $\mathrm{ft}^{3} / \mathrm{s}$

Water-surface elevation in bridge opening $491.0 \quad$ it

Area of flow in bridge opening $\quad 275 \quad \mathrm{ft}^{2}$

Average velocity in bridge opening $\quad 17.4 \quad \mathrm{ft} / \mathrm{s}$

Maximum WSPRO tube velocity at bridge $\quad 22.3 \mathrm{ft} / \mathrm{s}$

Water-surface elevation at Approach section with bridge

Water-surface elevation at Approach section without bridge

497.0

Amount of backwater caused by bridge $\quad 5.5$.t 


\section{Scour Analysis Summary}

\section{Special Conditions or Assumptions Made in Scour Analysis}

Scour depths were computed using the general guidelines described in Hydraulic Engineering Circular 18 (Richardson and others, 1993). Scour depths were calculated assuming an infinite depth of erosive material and a homogeneous particle-size distribution. The results of the scour analysis are presented in tables 1 and 2 and a graph of the scour depths is presented in figure 8 .

The 500-year discharge resulted in unsubmerged orifice flow. Contraction scour at bridges with orifice flow is best estimated by use of the Chang pressure-flow scour equation (oral communication, J. Sterling Jones, October 4, 1996). Therefore, contraction scour for the 500-year discharge was computed by use of the Chang equation (Richardson and others, 1995, p. 145-146). Contraction scour was computed by use of the clear-water contraction scour equation (Richardson and others, 1993, p. 35, equation 18) for the 100-year and incipient road over-flow discharges. For contraction scour computations, the average depth in the contracted section (AREA/TOPWIDTH) is subtracted from the depth of flow computed by the scour equation (Y2) to determine the actual amount of scour.

Abutment scour was computed by use of the Froehlich equation (Richardson and others, 1993, p. 49, equation 24). Variables for the Froehlich equation include the Froude number of the flow approaching the embankments, the length of the embankment blocking flow, and the depth of flow approaching the embankment less any roadway overtopping.

In this case, the incipient road-overflow discharge model resulted in the worst case contraction scour and the worst case total scour. Furthermore, because contraction scour and total scour depths were greater for the 100-year event than the 500-year event, figure 7 does not show the 500-year scour depths. 


\section{Scour Results}

100-yr discharge 500-yr discharge

Contraction scour:

(Scour depths in feet)

Main channel

Live-bed scour

Clear-water scour

Depth to armoring

Left overbank

Right overbank

Local scour:

Abutment scour

Left abutment

19.5

23.2

21.8

17.5

18.9-

19.4-

\section{Right abutment}

Pier scour

Pier 1

Pier 2

Pier 3

Abutments:

Left abutment

Right abutment

Piers:

Pier 1

Pier 2

\section{Riprap Sizing}

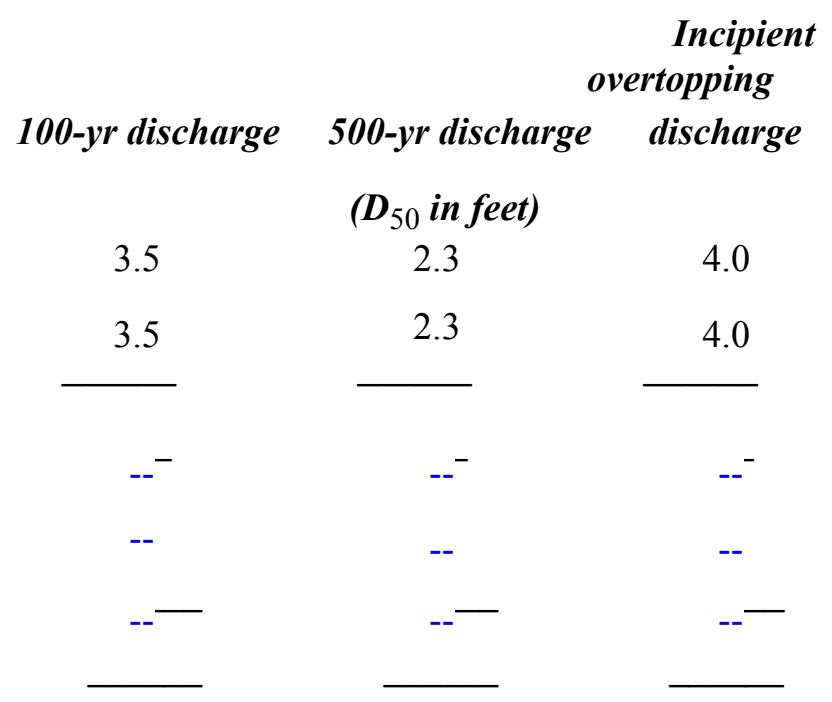




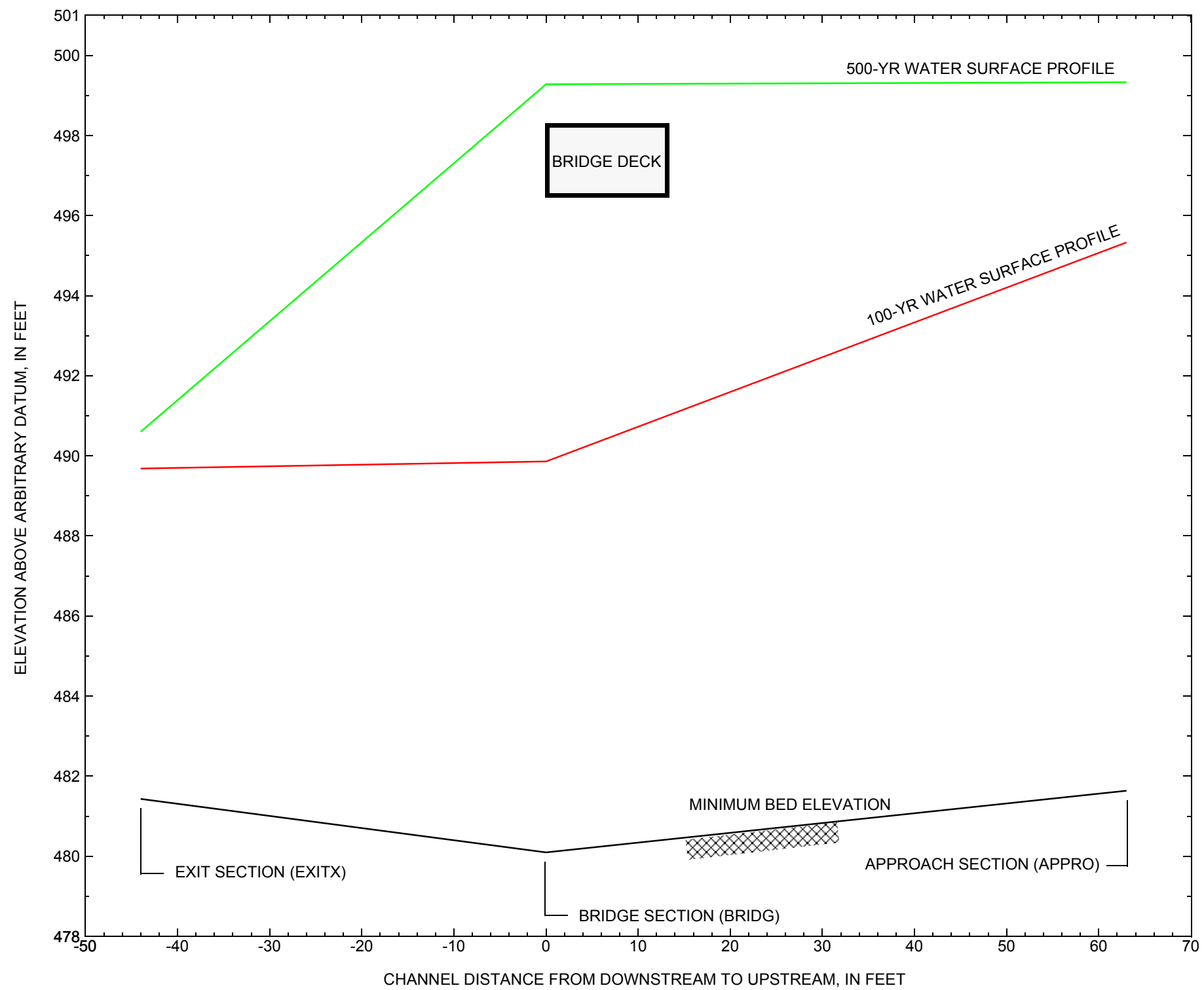

Figure 7. Water-surface profiles for the 100- and 500-yr discharges at structure BRNATH00800016 on town highway 80, crossing Locust Creek, Barnard, Vermont. 


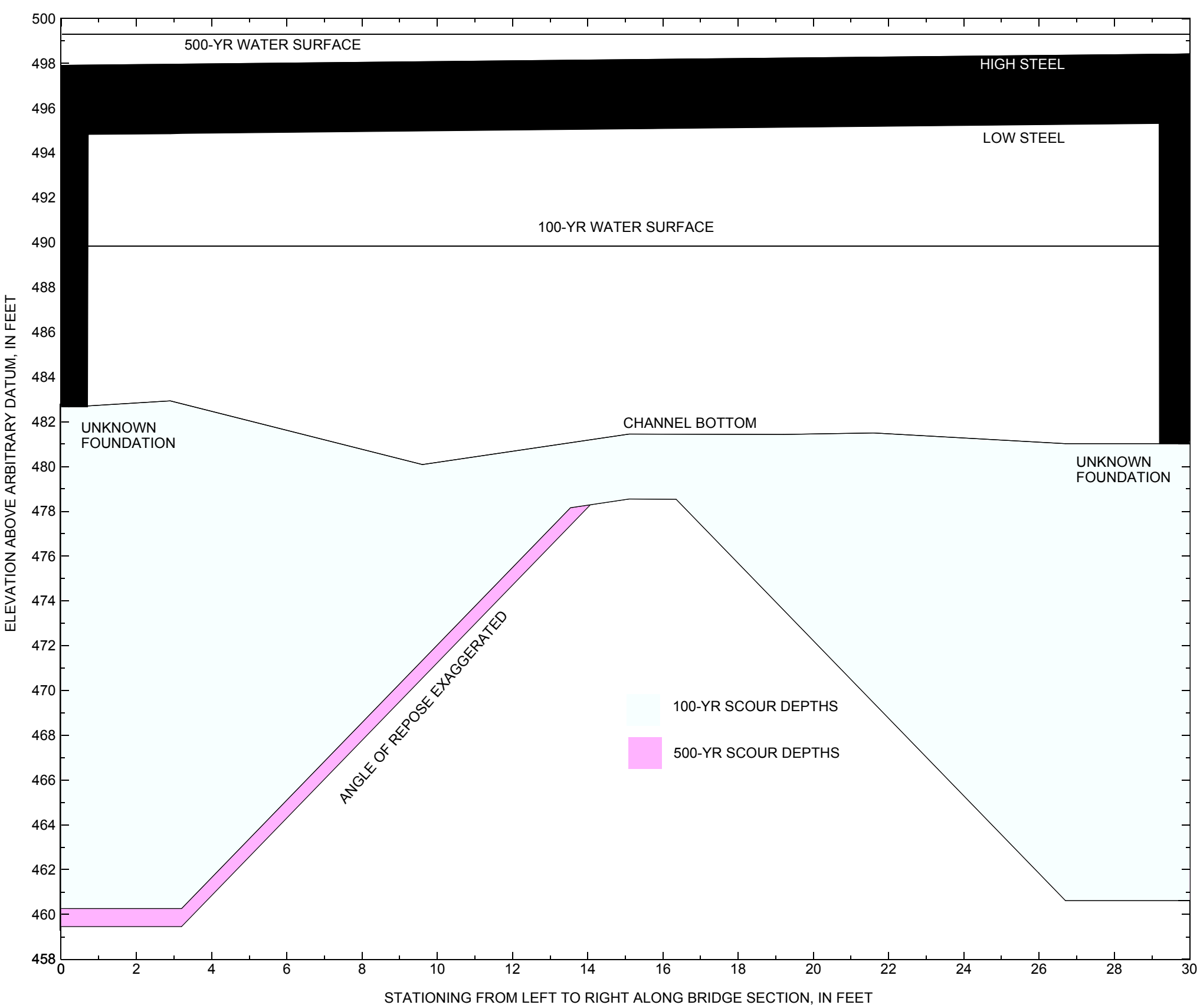

Figure 8. Scour elevations for the 100-year discharge at structure BRNATH00800016 on town highway 80, crossing Locust Creek, Barnard, Vermont. 
Table 1. Remaining footing/pile depth at abutments for the 100-year discharge at structure BRNATH00800016 on Town Highway 80, crossing Locust Creek, Barnard, Vermont.

[VTAOT, Vermont Agency of Transportation; --,no data]

\begin{tabular}{|c|c|c|c|c|c|c|c|c|c|c|c|}
\hline Description & Station $^{1}$ & $\begin{array}{l}\text { VTAOT } \\
\text { minimum } \\
\text { low-chord } \\
\text { elevation } \\
\text { (feet) }\end{array}$ & $\begin{array}{l}\text { Surveyed } \\
\text { minimum } \\
\text { low-chord } \\
\text { elevation } \\
\text { (feet) }\end{array}$ & $\begin{array}{c}\text { Bottom of } \\
\text { footing } \\
\text { elevation } \\
\text { (feet) }\end{array}$ & $\begin{array}{l}\text { Channel } \\
\text { elevation at } \\
\text { abutment/ } \\
\text { pier }^{2} \\
\text { (feet) }\end{array}$ & $\begin{array}{l}\text { Contraction } \\
\text { scour depth } \\
\text { (feet) }\end{array}$ & $\begin{array}{l}\text { Abutment } \\
\text { scour } \\
\text { depth } \\
\text { (feet) }\end{array}$ & $\begin{array}{l}\text { Pier } \\
\text { scour } \\
\text { depth } \\
\text { (feet) }\end{array}$ & $\begin{array}{l}\text { Depth of } \\
\text { total scour } \\
\text { (feet) }\end{array}$ & $\begin{array}{c}\text { Elevation of } \\
\text { scour }^{2} \\
\text { (feet) }\end{array}$ & $\begin{array}{c}\text { Remaining } \\
\text { footing/pile } \\
\text { depth } \\
\text { (feet) }\end{array}$ \\
\hline \multicolumn{12}{|c|}{100 -yr. discharge is 4,000 cubic-feet per second } \\
\hline Left abutment & 0.0 & -- & 496.4 & -- & 482.7 & 2.9 & 19.5 & -- & 22.4 & 460.3 & -- \\
\hline Right abutment & 29.2 & -- & 496.8 & -- & 481.0 & 2.9 & 17.5 & -- & 20.4 & 460.6 & -- \\
\hline
\end{tabular}

1. Measured along the face of the most constricting side of the bridge.

2. Arbitrary datum for this study.

Table 2. Remaining footing/pile depth at abutments for the 500-year discharge at structure BRNATH00800016 on Town Highway 80, crossing Locust Creek, Barnard, Vermont.

[VTAOT, Vermont Agency of Transportation; --, no data]

\begin{tabular}{|c|c|c|c|c|c|c|c|c|c|c|c|}
\hline Description & Station $^{1}$ & $\begin{array}{l}\text { VTAOT } \\
\text { minimum } \\
\text { low-chord } \\
\text { elevation } \\
\text { (feet) }\end{array}$ & $\begin{array}{c}\text { Surveyed } \\
\text { minimum } \\
\text { low-chord } \\
\text { elevation }{ }^{2} \\
\text { (feet) }\end{array}$ & $\begin{array}{c}\text { Bottom of } \\
\text { footing } \\
\text { elevation } \\
\text { (feet) }\end{array}$ & $\begin{array}{c}\text { Channel } \\
\text { elevation at } \\
\text { abutment/ } \\
\text { pier }^{2} \\
\text { (feet) }\end{array}$ & $\begin{array}{l}\text { Contraction } \\
\text { scour depth } \\
\text { (feet) }\end{array}$ & $\begin{array}{l}\text { Abutment } \\
\text { scour } \\
\text { depth } \\
\text { (feet) }\end{array}$ & $\begin{array}{l}\text { Pier } \\
\text { scour } \\
\text { depth } \\
\text { (feet) }\end{array}$ & $\begin{array}{l}\text { Depth of } \\
\text { total scour } \\
\text { (feet) }\end{array}$ & $\begin{array}{c}\text { Elevation of } \\
\text { scour }^{2} \\
\text { (feet) }\end{array}$ & $\begin{array}{c}\text { Remaining } \\
\text { footing/pile } \\
\text { depth } \\
\text { (feet) }\end{array}$ \\
\hline \multicolumn{12}{|c|}{500 -yr. discharge is 5,100 cubic-feet per second } \\
\hline Left abutment & 0.0 & -- & 496.4 & -- & 482.7 & 0.0 & 23.2 & -- & 23.2 & 459.5 & -- \\
\hline Right abutment & 29.2 & -- & 496.8 & -- & 481.0 & 0.0 & 18.9 & -- & 18.9 & 462.1 & -- \\
\hline
\end{tabular}

1. Measured along the face of the most constricting side of the bridge.

2. Arbitrary datum for this study. 


\section{SELECTED REFERENCES}

Arcement, G.J., Jr., and Schneider, V.R., 1989, Guide for selecting Manning's roughness coefficients for natural channels and flood plains: U.S. Geological Survey Water-Supply Paper 2339, 38 p.

Barnes, H.H., Jr., 1967, Roughness characteristics of natural channels: U.S. Geological Survey Water-Supply Paper 1849, 213 p.

Brown, S.A. and Clyde, E.S., 1989, Design of riprap revetment: Federal Highway Administration Hydraulic Engineering Circular No. 11, Publication FHWA-IP-89-016, 156 p.

Federal Highway Administration, 1983, Runoff estimates for small watersheds and development of sound design: Federal Highway Administration Report FHWA-RD-77-158

Froehlich, D.C., 1989, Local scour at bridge abutments in Ports, M.A., ed., Hydraulic Engineering--Proceedings of the 1989 National Conference on Hydraulic Engineering: New York, American Society of Civil Engineers, p. 13-18.

Hayes, D.C.,1993, Site selection and collection of bridge-scour data in Delaware, Maryland, and Virginia: U.S. Geological Survey Water-Resources Investigation Report 93-4017, 23 p.

Interagency Advisory Committee on Water Data, 1982, Guidelines for determining flood flow frequency: U.S. Geological Survey, Bulletin 17B of the Hydrology Subcommittee, $190 \mathrm{p}$.

Johnson, C.G. and Tasker, G.D.,1974, Progress report on flood magnitude and frequency of Vermont streams: U.S. Geological Survey Open-File Report 74-130, 37 p.

Lagasse, P.F., Schall, J.D., Johnson, F., Richardson, E.V., Chang, F., 1995, Stream Stability at Highway Structures: Federal Highway Administration Hydraulic Engineering Circular No. 20, Publication FHWA-IP-90-014, 144 p.

Laursen, E.M., 1960, Scour at bridge crossings: Journal of the Hydraulics Division, American Society of Civil Engineers, v. 86, no. HY2, p. 39-53.

Potter, W. D., 1957a, Peak rates of runoff in the Adirondack, White Mountains, and Maine woods area, Bureau of Public Roads

Potter, W. D., 1957b, Peak rates of runoff in the New England Hill and Lowland area, Bureau of Public Roads

Richardson, E.V. and Davis, S.R., 1995, Evaluating scour at bridges: Federal Highway Administration Hydraulic Engineering Circular No. 18, Publication FHWA-IP-90-017, 204 p.

Richardson, E.V., Simons, D.B., and Julien, P.Y., 1990, Highways in the river environment: Federal Highway Administration Publication FHWA-HI-90-016.

Ritter, D.F., 1984, Process Geomorphology: W.C. Brown Co., Debuque, Iowa, 603 p.

Shearman, J.O., 1990, User's manual for WSPRO--a computer model for water surface profile computations: Federal Highway Administration Publication FHWA-IP-89-027, 187 p.

Shearman, J.O., Kirby, W.H., Schneider, V.R., and Flippo, H.N., 1986, Bridge waterways analysis model; research report: Federal Highway Administration Publication FHWA-RD-86-108, 112 p.

Talbot, A.N., 1887, The determination of water-way for bridges and culverts.

U.S. Department of Transportation, 1993, Stream stability and scour at highway bridges, Participant Workbook: Federal Highway Administration Publication FHWA HI-91-011.

U.S. Geological Survey, 1980, Bethel, Vermont 7.5 Minute Series quadrangle map: U.S. Geological Survey Topographic Maps, Scale 1:24,000. 


\section{APPENDIX A: \\ WSPRO INPUT FILE}




\section{WSPRO INPUT FILE}

\section{*}

BR

GR

GR

GR

GR

GR

$\mathrm{N}$

CD

*

XR

GR

GR

GR

GR

*

XT

GR

GR

GR

GR

*

AS APPRO 63

$\mathrm{GT}$

$\mathrm{N}$

*

HP 1 BRIDG

HP 2 BRIDG

HP 1 APPRO

HP 2 APPRO

*

HP 1 BRIDG

HP 2 BRIDG

HP 2 RDWAY

HP 1 APPRO

HP 2 APPRO

*

HP 1 BRIDG

HP 2 BRIDG

HP 1 APPRO
U.S. GEOLOGICAL SURVEY WSPRO INPUT FILE brna016.wsP CREATED ON 13-NOV-95 FOR BRIDGE BRNATH00800016 USING FILE brna016.dCa Hydraulic analysis of Barnard 016 by MAI

$62930 \quad 552 \quad 553 \quad 551516 \quad 17 \quad 13 \quad 3 * \begin{array}{lllllllllll}15 & 14 & 23 & 21 & 11 & 12 & 4 & 7 & 3\end{array}$

$4000.0 \quad 4800.0 \quad 5100.0$

$\begin{array}{lll}0.012 & 0.012 & 0.012\end{array}$

0 .

$$
-59.1,499.76
$$

$0.0,482.40$

$-39.3,489.26$

$-20.0,485.90$

$-4.7,484.37$

$0.1,482.42$

$14.5,481.51$

$20.7,481.43$

$37.3,482.59$

$38.7,483.53$

$47.4,486.40$

$53.4,492.17$

$74.6,498.74$

0.060

\section{$0 *$ * * 0.005}

$0 \quad 496.7$

$0.0,496.41$

$5.3,480.63$

$0.7,482.66$

$2.9,482.93$

$5.1,482.07$

$7.8,480.28$

$9.6,480.09$

$12.1,480.49$

$19.2,481.43$

$21.6,481.50$

$24.4,481.09$

$26.7,481.02$

$27.1,482.75$

$28.3,482.79$

$29.2,483.24$

$0.0,496.41$

0.055

134.1 * * 5510.4

$$
\begin{array}{rrr}
10 & 12.9 & 2 \\
-81.7, & 503.08 & -66 \\
-17.9, & 499.22 & - \\
38.3, & 499.00 & 51 \\
98.9, & 502.30 & 102 \\
& & \\
77 & & 0 . \\
0.7, & 504.82 & -3 \\
15.1, & 483.04 & 1 \\
37.7, & 486.40 & 4
\end{array}
$$

$-66.5,500.87$

$-3.3,498.17$

$51.3,499.62$

$102.5,501.97$

0 .

$-0.46$

0.060

489.861489 .86

489.86 * 44000

495.331495 .33

$495.33 * * 4000$

496.821496 .82

496.82 * 44868

499.28 * 215

499.331499 .33

499.33 * * 5100

490.971490 .97

490.97 * * 4800

496.961496 .96
$-31.8,491.30$

$0.0,483.52$

$19.3,482.87$

$48.6,491.96$

$$
\begin{array}{rrr}
-45.7,500.48 & -28.9, & 499.98 \\
0.0,497.91 & 29.7, & 498.42 \\
61.5, & 499.60 & 72.3,500.74 \\
106.6,500.59 & 113.2,502.70
\end{array}
$$

$-20.8,489.59$

$5.1,482.91$

$25.4,482.09$

$53.9,498.28$

$$
\begin{array}{rr}
-15.4, & 487.66 \\
11.2, & 482.48 \\
30.4, & 483.69 \\
72.7, & 502.82
\end{array}
$$




\section{APPENDIX B: \\ WSPRO OUTPUT FILE}




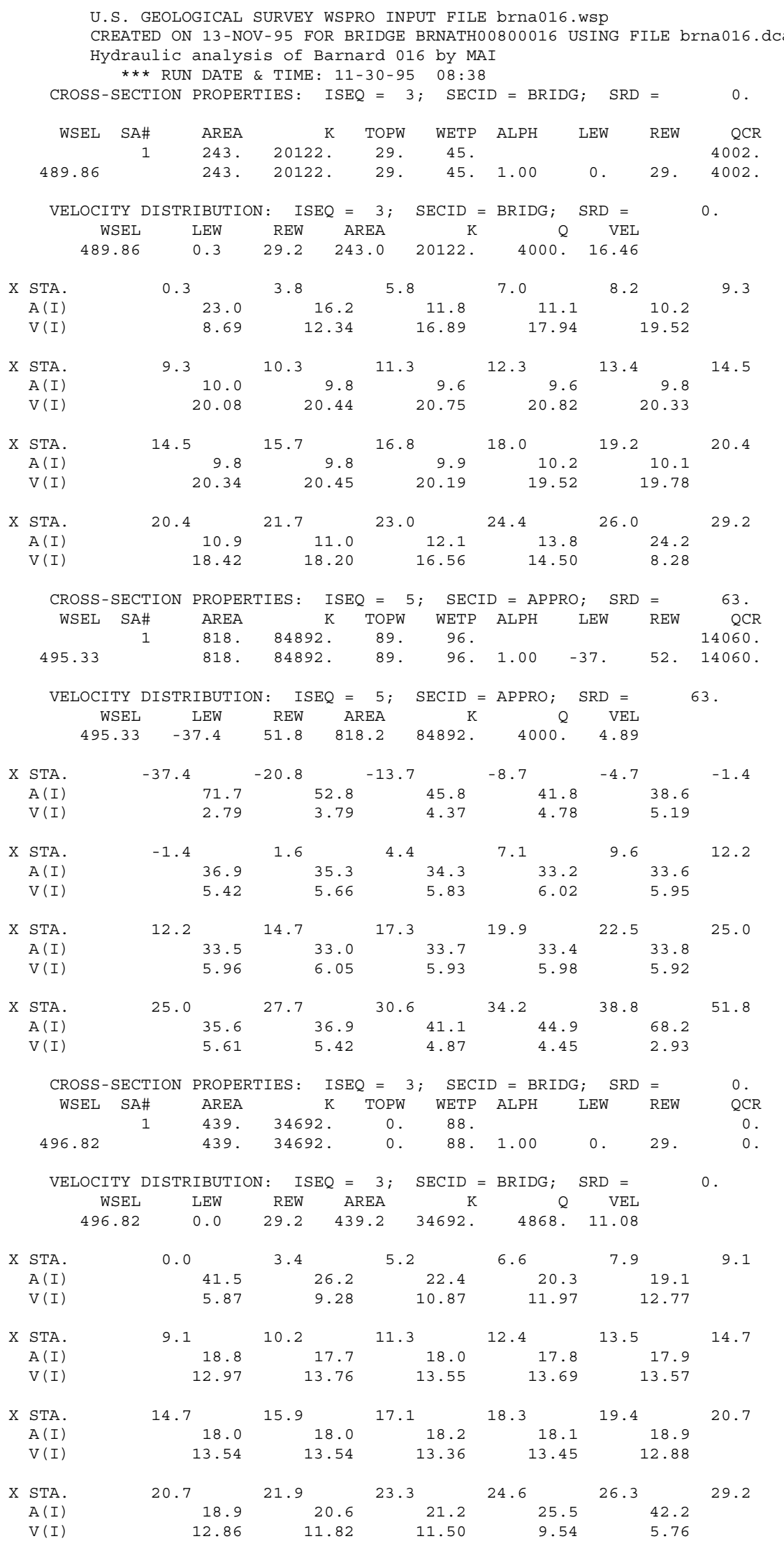


WSPRO OUTPUT FILE (continued)

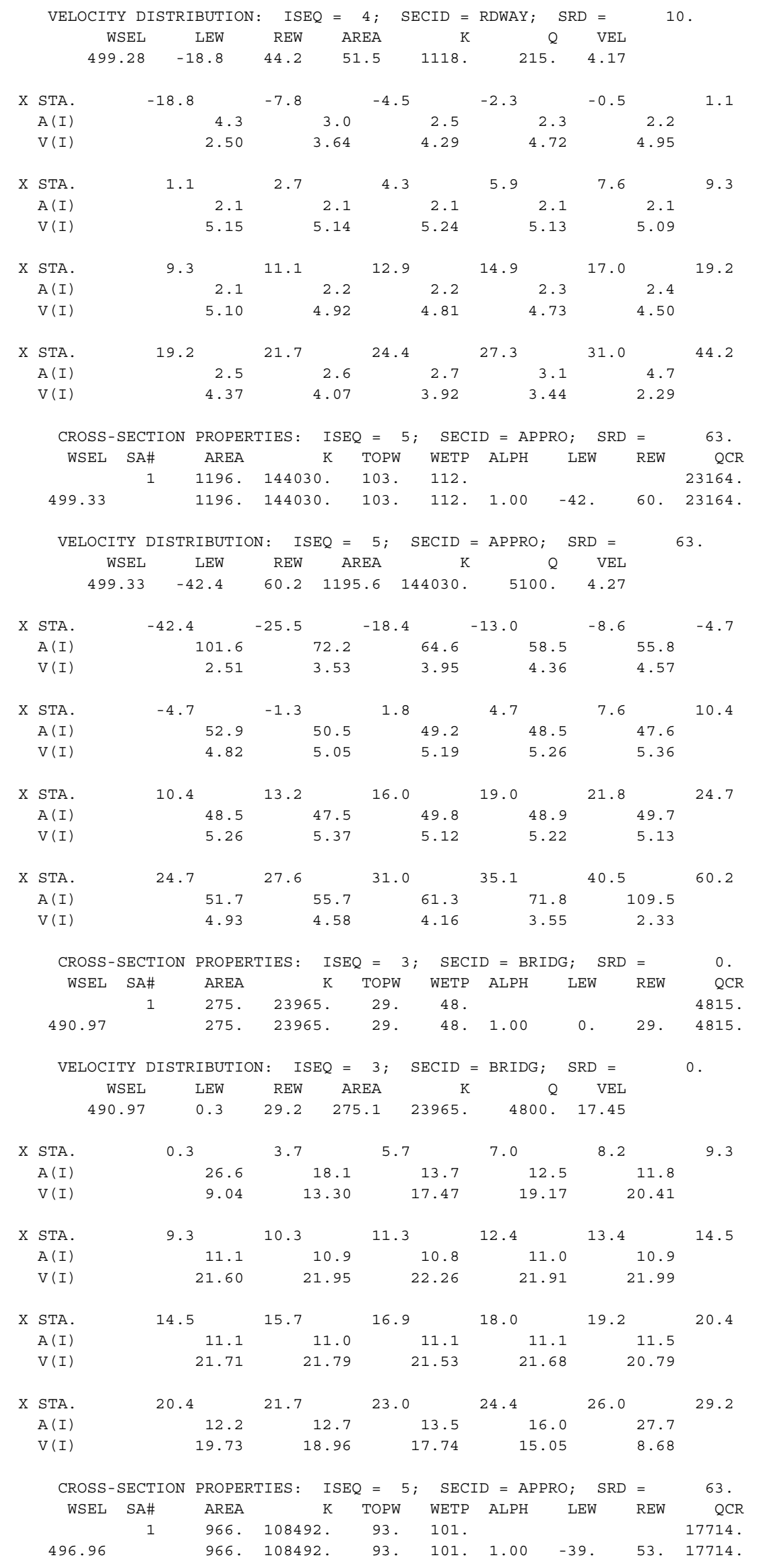




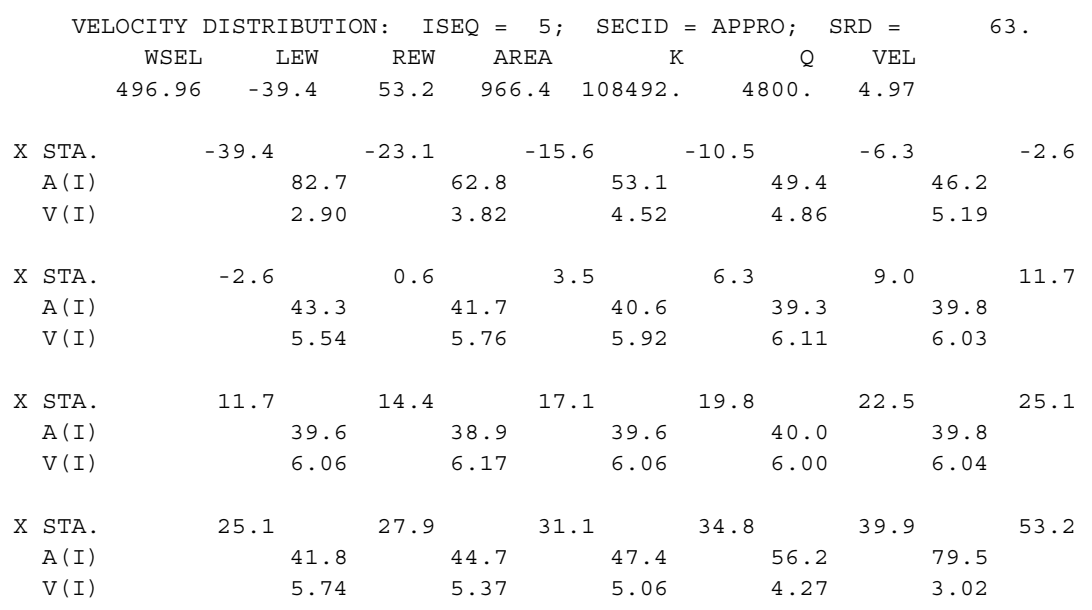

U.S. GEOLOGICAL SURVEY WSPRO INPUT FILE brna016.wsp

CREATED ON 13-NOV-95 FOR BRIDGE BRNATH00800016 USING FILE brna016.dca Hydraulic analysis of Barnard 016 by MAI

*** RUN DATE \& TIME: 11-30-95 08:38

\begin{tabular}{|c|c|c|c|c|c|c|c|c|c|}
\hline XSID : CODE & SRDL & LEW & AREA & VHD & $\mathrm{HF}$ & EGL & CRWS & Q & WSEL \\
\hline SRD & FLEN & REW & K & $\mathrm{ALPH}$ & $\mathrm{HO}$ & ERR & FR\# & \multicolumn{2}{|l|}{ VEL } \\
\hline EXIT-:XS & $\star * \star * \star * *$ & -40 & 490. & 1.04 & $\star * \star * \star *$ & 490.72 & 488.00 & 4000 & 489.68 \\
\hline-44 & $\star \star \star \star \star * *$ & 51. & 36511. & 1.00 & $\star * * * *$ & $\star * \star * * \star * *$ & 0.62 & 8.17 & \\
\hline FULLV : FV & 44. & -41 & 525. & 0.90 & 0.47 & 491.19 & 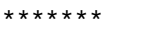 & 4000 & 490.29 \\
\hline 0 . & 44. & 51. & 40601. & 1.00 & 0.00 & 0.00 & 0.56 & 7.62 & \\
\hline$<$ & $<<<\mathrm{THE}$ & BOVE $\mathrm{F}$ & SULTS R & FLECT & "NORMz & (UNC & NSTRICTED) & FLOW & $>>>$ \\
\hline
\end{tabular}

APPRO:AS 63. $\quad$-32. $438.1 .29 \quad 0.75 \quad 492.13 * * * * * * * \quad 4000.490 .83$

63. 63. 47. 33262. $\quad \begin{array}{llllll}\text { 63.00 } & 0.20 & 0.00 & 0.68 & 9.12\end{array}$

<<<<THE ABOVE RESULTS REFLECT "NORMAL" (UNCONSTRICTED) FLOW >>>>>

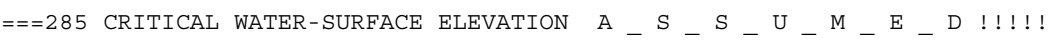

SECID "BRIDG" $Q$, CRWS $=400 \overline{0} .-4 \overline{8} 9.8 \overline{6}$

$<<<<$ RESULTS REFLECTING THE CONSTRICTED FLOW FOLLOW $>>>>>$

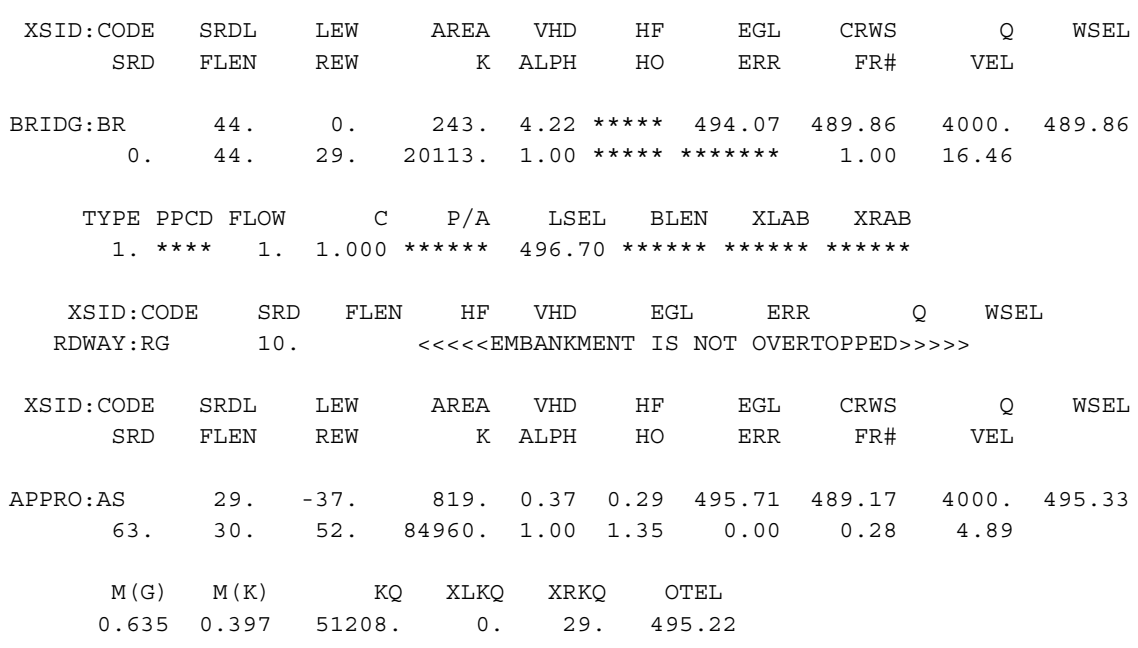


WSPRO OUTPUT FILE (continued)

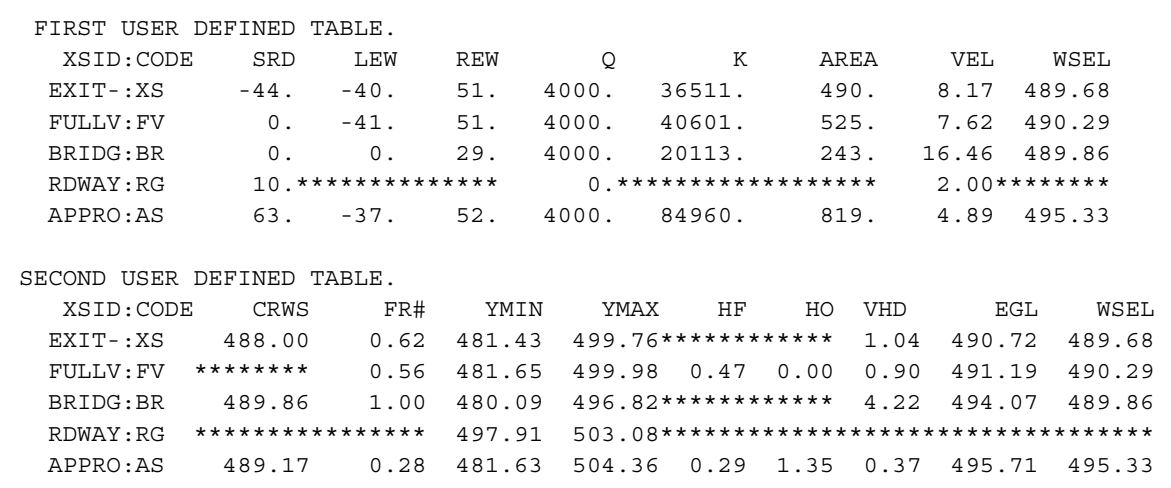

\footnotetext{
U.S. GEOLOGICAL SURVEY WSPRO INPUT FILE brna016.wsp

CREATED ON 13-NOV-95 FOR BRIDGE BRNATH00800016 USING FILE brna016.dca Hydraulic analysis of Barnard 016 by MAI *** RUN DATE \& TIME: 11-30-95 08:38

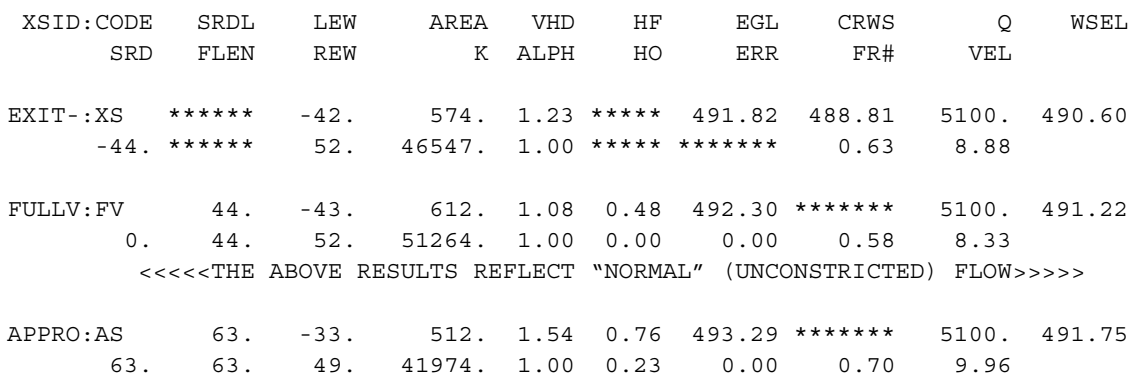


WSPRO OUTPUT FILE (continued)

\begin{tabular}{|c|c|c|c|c|c|c|c|c|c|}
\hline XSID : CODE & CRWS & FR\# & YMIN & YMAX & $\mathrm{HF}$ & HO & VHD & EGL & WSEL \\
\hline EXIT-:XS & 488.81 & 0.63 & 481.43 & $499.76 *$ & $* * * \star * * *$ & $\star * * * *$ & 1.23 & 491.82 & 490.60 \\
\hline FULLV : FV & $\star \star \star \star \star \star * \star * *$ & 0.58 & 481.65 & 499.98 & 0.48 & 0.00 & 1.08 & 492.30 & 491.22 \\
\hline BRIDG : BR & 491.05 & 0.50 & 480.09 & $496.82 *$ & $* * \star * * * *$ & $\star \star \star \star \star *$ & 1.91 & 498.73 & 496.82 \\
\hline RDWAY : RG & $\star \star \star \star \star \star \star * \star * \star *$ & $* \star \star \star *$ & 497.91 & 503.08 & $0.06 * x$ & $\star * \star * *$ & 0.28 & 499.55 & 499.28 \\
\hline APPRO:AS & 490.21 & 0.22 & 481.63 & 504.36 & 0.15 & 1.39 & 0.28 & 499.62 & 499.33 \\
\hline
\end{tabular}

\footnotetext{
U.S. GEOLOGICAL SURVEY WSPRO INPUT FILE brna016.wsp CREATED ON 13-NOV-95 FOR BRIDGE BRNATH00800016 USING FILE brna016.dCa Hydraulic analysis of Barnard 016 by MAI

*** RUN DATE \& TIME: 11-30-95 08:38

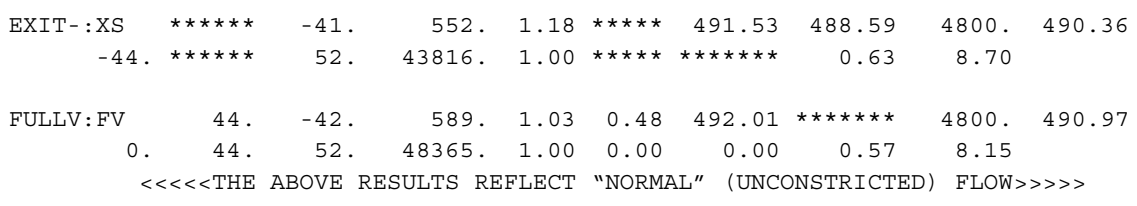




\section{APPENDIX C:}

\section{BED-MATERIAL PARTICAL-SIZE DISTRIBUTION}




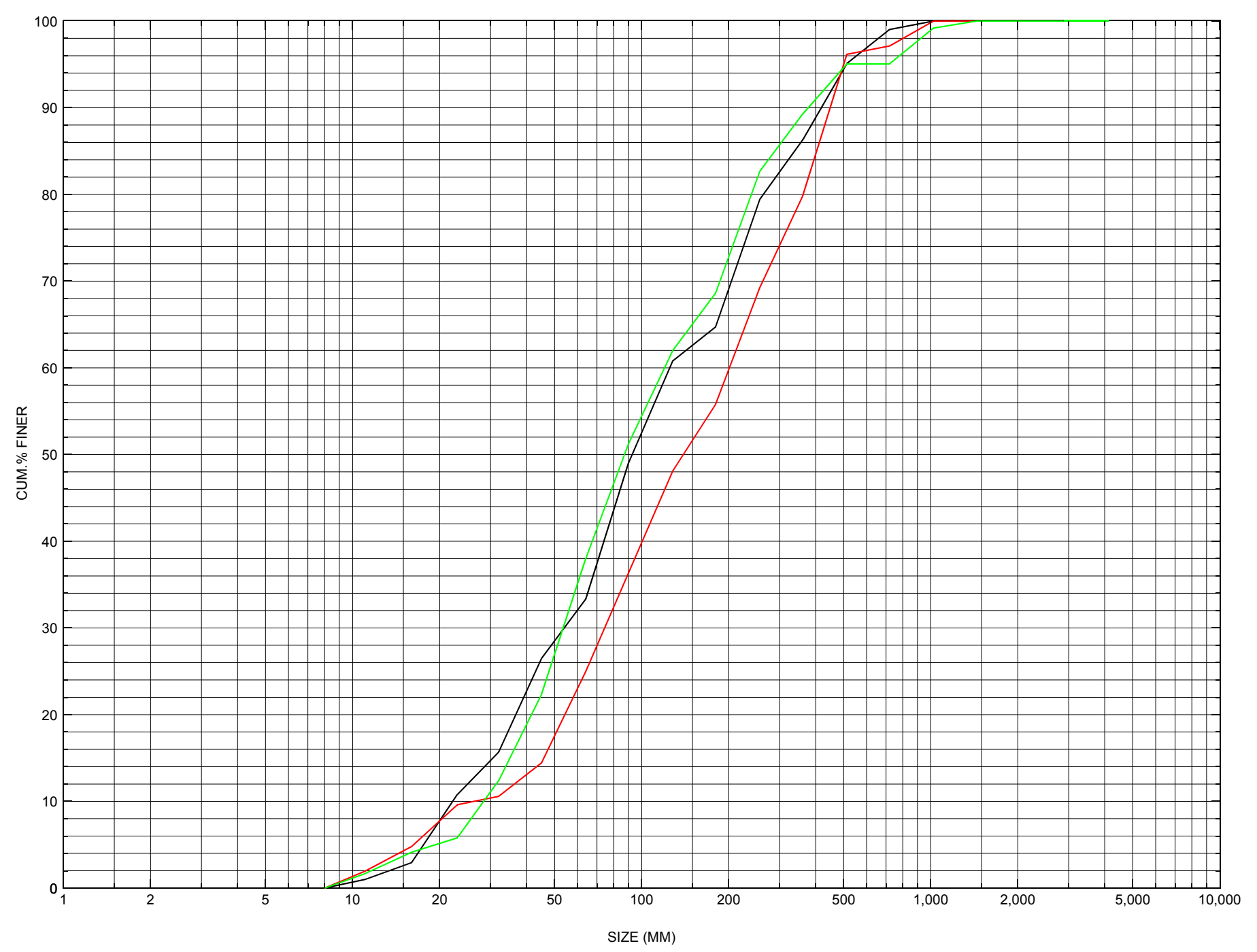

Appendix C. Bed material particle-size distributions for three pebble count transects at the approach cross-section for structure BRNATH00800016, in Barnard, Vermont. 


\section{APPENDIX D: \\ HISTORICAL DATA FORM}




\section{Structure Number BRNATH00800016}

\section{General Location Descriptive}

Data collected by (First Initial, Full last name) M. IVANOFF

Date $(M M / D D / Y Y) \_\mathbf{0 8} / \underline{\mathbf{2 3}} / \underline{\mathbf{9 4}}$

Highway District Number (I - 2; nn) 04

Town (FIPS place code; I - 4; nnnnn) $\mathbf{0 2 7 2 5}$

Waterway (I - 6) LOCUST CREEK

Route Number $\underline{\mathbf{T H 0 8 0}}$

Topographic Map Bethel

Latitude (I - 16; nnnn.n) $\mathbf{4 3 4 7 2}$
County (FIPS county code; I - 3; nnn)

Mile marker (I - 11; nnn.nnn) $\mathbf{0 0 0 0 0 0}$

Road Name (I - 7): -

Vicinity (I - 9) 0.01 MI TO JCT W VT12

Hydrologic Unit Code: $\mathbf{0 1 0 8 0 1 0 5}$

Longitude (i - 17; nnnnn.n) $\mathbf{7 2 3 8 5}$

\section{Select Federal Inventory Codes}

FHWA Structure Number (I - 8) 10140300161403

Maintenance responsibility $(I-21 ; n n) \quad \mathbf{0 3} \quad$ Maximum span length $(I-48 ; n n n n) \underline{\mathbf{0 0 3 3}}$

Year built (I - 27; YYYY) 1971

Structure length (I - 49; nnnnnn) $\underline{\mathbf{0 0 0 0 3 6}}$

Average daily traffic, ADT (I - 29; nnnnnn) $\underline{000020}$

Deck Width (I - 52; nn.n) 129

Year of ADT (I - 30; YY) $\mathbf{9 0}$

Channel \& Protection $(I-61 ; n) \underline{\mathbf{6}}$

Opening skew to Roadway $(I-34 ; n n) \quad \mathbf{0 0}$

Waterway adequacy $(I-71 ; n) \underline{6}$

Operational status $(I-41 ; X) \mathbf{P}$

Underwater Inspection Frequency $(I-92 B ; X Y Y) \_\mathbf{N}$

Structure type (I - 43; nnn) $\mathbf{3 0 2}$

Year Reconstructed (I - 106) $\mathbf{0 0 0 0}$

Approach span structure type (I - 44; nnn) $\mathbf{0 0 0}$

Clear span (nnn.n ft)

Number of spans (I - 45; nnn) $\mathbf{0 0 1}$

Vertical clearance from streambed (nnn.n ft) $\underline{\mathbf{0 1 5 . 0}}$

Number of approach spans $(I-46 ; n n n n) \underline{\mathbf{0 0 0 0}}$ Waterway of full opening $\left(n n n . n f^{2}\right) \quad \mathbf{4 9 5 . 0}$

Comments:

Structural inspection report of 6/6/94 indicates some random heavy rotting of timber at bridge seat with no severe timber displacement. The upstream right wingwall leans forward 18 inches at top and has rotten logs. The left abutment has a free poured concrete footing. The report noted only minor channel scour and no embankment erosion. No apparent settlement or undermining. No drift/vegetation is indicated. Channel alignment is straight through the crossing. Stone fill and boulders along the banks. 


\section{Bridge Hydrologic Data}

Is there hydrologic data available? $\mathbf{Y}$ if No, type ctrl-n $h \quad$ VTAOT Drainage area $\left(m i^{2}\right): \underline{\mathbf{2 2 . 2}}$

Terrain character: Hilly to mountainous, mostly forested

Stream character \& type: -

Streambed material: GRAVEL TO COBBLE

Discharge Data (cfs): $\quad \mathrm{Q}_{2.33} \frac{\mathbf{8 0 0}}{\mathbf{2 7 5 0}}$

$\mathrm{Q}_{50} \overline{\mathbf{2 7 5 0}}$

\begin{tabular}{ll}
$Q_{10} \frac{\mathbf{1 7 0 0}}{\mathbf{3 3 0 0}}$ & $\mathrm{Q}_{25} \stackrel{\mathbf{2 3 0 0}}{\mathrm{Q}_{100}} \mathrm{Q}_{500}-$ \\
\hline
\end{tabular}

Record flood date $(M M / D D / Y Y):-I^{\prime}-l^{\prime}-\quad$ Water surface elevation (ft): -

Estimated Discharge (cfs): _ _ Velocity at $\mathrm{Q}$ - _ $(\mathrm{ft} / \mathrm{s}):$

Ice conditions (Heavy, Moderate, Light) : LIGHT Debris (Heavy, Moderate, Light): LIGHT

The stage increases to maximum highwater elevation (Rapidly, Not rapidly): -

The stream response is (Flashy, Not flashy):

Describe any significant site conditions upstream or downstream that may influence the stream's stage: -

Watershed storage area (in percent):

The watershed storage area is: - _ (1-mainly at the headwaters; 2- uniformly distributed; 3-immediatly upstream oi the site)

Water Surface Elevation Estimates for Existing Structure:

\begin{tabular}{|l|l|c|c|l|l|}
\hline Peak discharge frequency & $Q_{2.33}$ & $Q_{10}$ & $Q_{25}$ & $Q_{50}$ & $Q_{100}$ \\
Water surface elevation (ft)) & $\mathbf{7 3 4 . 7}$ & $\mathbf{7 3 6 . 9}$ & $\mathbf{7 3 8 . 2}$ & $\mathbf{7 3 9 . 2}$ & $\mathbf{7 4 0 . 3}$ \\
Velocity $(\mathrm{ft} / \mathrm{sec})$ & - & - & - & - & - \\
\hline
\end{tabular}

Long term stream bed changes: -

Is the roadway overtopped below the $\mathrm{Q}_{100}$ ? (Yes, No, Unknown): $\mathbf{U} \quad$ Frequency: -

Relief Elevation $(f t)$ :

Discharge over roadway at $\mathrm{Q}_{100}\left(f^{3} / \mathrm{sec}\right)$ : -

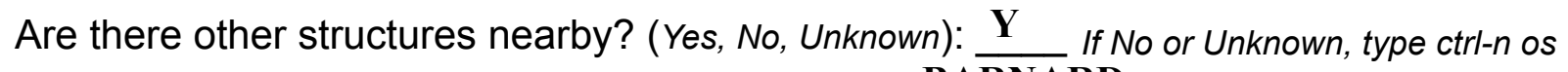
Upstream distance (miles): $\mathbf{0 . 1}$ Town: BARNARD $\quad$ Year Built: Highway No. : VT12 Structure No. : 27 Structure Type: CONC. WF BEAM Clear span (ft): $\underline{\mathbf{8 6}}$ Clear Height $(f t): \underline{14}$ Full Waterway $\left(f t^{2}\right):$ 
Downstream distance (miles): $\underline{0.5}$ Town: Barnard Year Built:

Highway No. : TH68 Structure No. : 3

Clear span (ft): $\underline{\mathbf{3 0}}$ Clear Height $(f t): \underline{10}$ Structure Type: Bridge

Comments:

Design flow is Q25. The upstream bridge full waterway is noted as 900 square feet.

\section{USGS Watershed Data}

Watershed Hydrographic Data

Drainage area $(D A) \stackrel{\mathbf{2 2 . 0 2}}{\mathrm{mi}^{2}}$ $\mathrm{mi}^{2} \quad$ Lake and pond area $\mathbf{0 . 1 8}$ $\mathrm{mi}^{2}$

Watershed storage (ST)

Bridge site elevation 720 0.8 $\%$

Main channel length 10.24 $\mathrm{ft}$

Headwater elevation 2836 $\mathrm{ft}$ $10 \%$ channel length elevation $\mathbf{7 9 0}$ $\mathrm{ft} \quad 85 \%$ channel length elevation $\mathrm{ft}$

Main channel slope (S)

(S) 132.81 $\mathrm{ft} / \mathrm{mi}$

Watershed Precipitation Data

Average site precipitation in Average headwater precipitation in

Maximum 2yr-24hr precipitation event $(124,2)$

2.5 in

Average seasonal snowfall (Sn) $\mathrm{ft}$ 


\section{Bridge Plan Data}

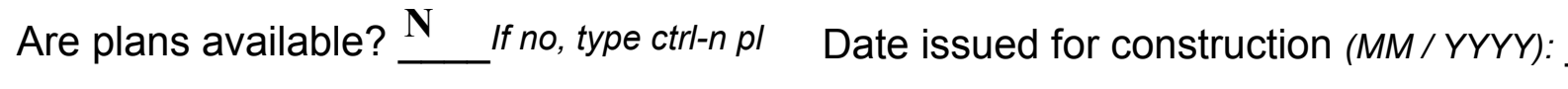

Project Number

Minimum channel bed elevation:

Low superstructure elevation: USLAB DSLAB USRAB DSRAB Benchmark location description:

NO BENCHMARK INFORMATION

Reference Point (MSL, Arbitrary, Other): Datum (NAD27, NAD83, Other):

Foundation Type: 4

If 1: Footing Thickness

If 2: Pile Type: (1-Wood; 2-Steel or metal; 3-Concrete)

If 3 : Footing bottom elevation:

Is boring information available? (1-Spreadfooting; 2-Pile; 3- Gravity; 4-Unknown)

Foundation Material Type: 3 If no, type ctrl-n bi Number of borings taken:

Briefly describe material at foundation bottom elevation or around piles:

NO FOUNDATION MATERIAL INFORMATION

Comments:

NO PLANS. 


\section{Cross-sectional Data}

Is cross-sectional data available? $\mathbf{N}$ If no, type ctrl-n xs

Source (FEMA, VTAOT, Other)? -

Comments: NO CROSS SECTION INFORMATION

\begin{tabular}{|l|l|l|l|l|l|l|l|l|l|l|l|}
\hline Station & - & - & - & - & - & - & - & - & - & - & - \\
\hline Feature & - & - & - & - & - & - & - & - & - & - & - \\
\hline $\begin{array}{l}\text { Low cord } \\
\text { elevation }\end{array}$ & - & - & - & - & - & - & - & - & - & - & - \\
\hline $\begin{array}{l}\text { Bed } \\
\text { elevation }\end{array}$ & - & - & - & - & - & - & - & - & - & - & - \\
\hline $\begin{array}{l}\text { Low cord to } \\
\text { bed length }\end{array}$ & - & - & - & - & - & - & - & - & - & - & - \\
\hline Station & - & - & - & - & - & - & - & - & - & - & - \\
\hline Feature & - & - & - & - & - & - & - & - & - & - & - \\
\hline $\begin{array}{l}\text { Low cord } \\
\text { elevation }\end{array}$ & - & - & - & - & - & - & - & - & - & - & - \\
\hline $\begin{array}{l}\text { Bed } \\
\text { elevation }\end{array}$ & - & - & - & - & - & - & - & - & - & - & - \\
\hline $\begin{array}{l}\text { Low cord to } \\
\text { bed length }\end{array}$ & - & - & - & - & - & - & - & - & - & - & - \\
\hline
\end{tabular}

Source (FEMA, VTAOT, Other)?

Comments: NO CROSS SECTION INFORMATION

\begin{tabular}{|l|l|l|l|l|l|l|l|l|l|l|l|}
\hline Station & - & - & - & - & - & - & - & - & - & - & - \\
\hline Feature & - & - & - & - & - & - & - & - & - & - & - \\
\hline $\begin{array}{l}\text { Low cord } \\
\text { elevation }\end{array}$ & - & - & - & - & - & - & - & - & - & - & - \\
\hline $\begin{array}{l}\text { Bed } \\
\text { elevation }\end{array}$ & - & - & - & - & - & - & - & - & - & - & - \\
\hline $\begin{array}{l}\text { Low cord to } \\
\text { bed length }\end{array}$ & - & - & - & - & - & - & - & - & - & - & - \\
\hline Station & - & - & - & - & - & - & - & - & - & - & - \\
\hline Feature & - & - & - & - & - & - & - & - & - & - & - \\
\hline $\begin{array}{l}\text { Low cord } \\
\text { elevation }\end{array}$ & - & - & - & - & - & - & - & - & - & - & - \\
\hline $\begin{array}{l}\text { Bed } \\
\text { elevation }\end{array}$ & - & - & - & - & - & - & - & - & - & - & - \\
\hline $\begin{array}{l}\text { Low cord to } \\
\text { bed length }\end{array}$ & - & - & - & - & - & - & - & - & - & - & - \\
\hline
\end{tabular}




\section{APPENDIX E: \\ LEVEL I DATA FORM}


U. S. Geological Survey

Bridge Field Data Collection and Processing Form

Qa/Qc Check by: MAI Date: $1 / 12 / 95$

\section{Structure Number BRNATH00800016} Computerized by: MAI Date: $\underline{1 / 12 / 95}$

Reviewd by: SAO Date: $\underline{1 / 19 / 96}$

\section{A. General Location Descriptive}

1. Data collected by (First Initial, Full last name) M. WEBER

2. Highway District Number 04

Mile marker 000000

County 027 (WINDSOR)

Town 02725 (BARNARD)

Waterway (l - 6) LOCUST CREEK

Route Number TH080

Road Name -

Hydrologic Unit Code: $\mathbf{0 1 0 8 0 1 0 5}$

3. Descriptive comments:

The bridge is 0.01 miles West from the intersection of VT12 and TH080. Additional information for this form was collected 12/15/94 by $\mathrm{S}$. Olson.

\section{B. Bridge Deck Observations}
4. Surface cover... LBUS 6
RBUS 5
LBDS 6
RBDS 5
Overall 5

(2b us, ds,lb,rb: 1- Urban; 2- Suburban; 3- Row crops; 4- Pasture; 5- Shrub- and brushland; 6- Forest; 7- Wetland)
5. Ambient water surface... US 2
UB 1
DS 1
(1- pool; 2- riffle)

6. Bridge structure type 1 (1- single span; 2- multiple span; 3- single arch; 4- multiple arch; 5-cylindrical culvert; 6- box culvert; or 7- other)
7. Bridge length $\mathbf{3 6}$
(feet)
Span length $\underline{\mathbf{3 3}}$
(feet)
Bridge width 12.9 (feet)

\section{Road approach to bridge:}
8. LB 2
RB 2
( 0 even, 1- lower, 2- higher)
9. LB_
RB $\underline{2}$
(1-Paved, 2- Not paved)

10. Embankment slope (run / rise in feet / foot)

US left

0.0:1

US right

0.0:1

\begin{tabular}{|c|c|c|c|c|}
\cline { 2 - 5 } & \multicolumn{2}{|c|}{ Protection } & \multirow{2}{*}{ 13.Erosion } & 14.Severity \\
\cline { 2 - 5 } LBUS & 11.Type & 12.Cond. & $\underline{\mathbf{0}}$ & $\underline{\mathbf{3}}$ \\
\cline { 2 - 5 } RBUS & - & - & $\mathbf{0}$ & $\mathbf{0}$ \\
RBDS & $\mathbf{0}$ & - & $\underline{\mathbf{2}}$ & $\mathbf{1}$ \\
\hline LBDS & $\mathbf{2}$ & $\mathbf{1}$ & $\mathbf{2}$ \\
\hline
\end{tabular}

Bank protection types: 0- none; 1- $<12$ inches;

2- < 36 inches; 3- < 48 inches;

4- < 60 inches; 5- wall / artificial levee

Bank protection conditions: 1- good; 2- slumped;

3- eroded; 4- failed

Erosion: 0 - none; 1- channel erosion; 2 -

road wash; 3- both; 4- other

Erosion Severity: 0 - none; 1- slight; 2- moderate; 3- severe

\section{Channel approach to bridge (BF):}

15. Angle of approach: $\mathbf{0}$

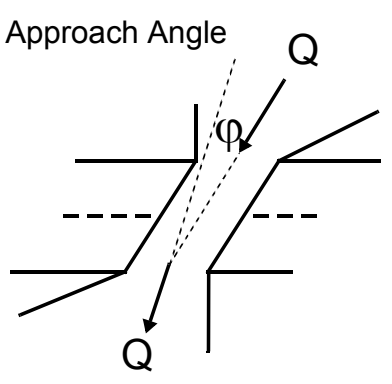

17. Channel impact zone 1 :

Where? $(L B, R B)$

Range? feet -

Channel impact zone 2:

Where? $(L B, R B)$

Range? - $\quad$ feet -

(US, UB, DS) to feet Impact Severity: 0- none to very slight; 1-Slight; 2- Moderate; 3- Severe

16. Bridge skew: $\mathbf{0}$ Bridge Skew Angle

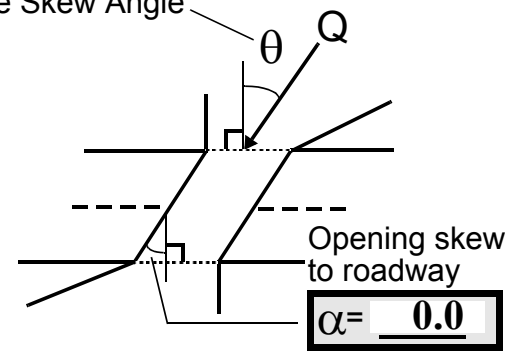

Exist? $\underline{\mathbf{N}}(\mathrm{Y}$ or $N)$

Severity -

(US, UB, DS) to -

Exist? $\mathbf{N}(Y$ or $N)$

Severity - 
18. Level II Bridge Type: 1a

1a- Vertical abutments with wingwalls

$1 \mathrm{~b}$ - Vertical abutments without wingwalls

2- Vertical abutments and wingwalls, sloping embankment Wingwalls perpendicular to abut. face

3- Spill through abutments

4- Sloping embankment, vertical wingwalls and abutments

Wingwall angle less than $90^{\circ}$.

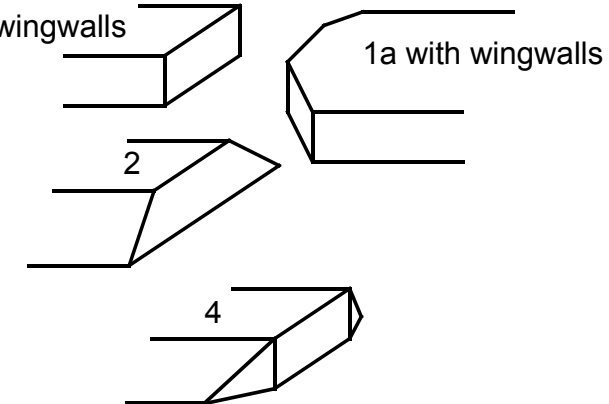

19. Bridge Deck Comments (surface cover variations, measured bridge and span lengths, bridge type variations, approach overflow width, etc.)

Measured; bridge length: $36 \mathrm{ft}$, span length: $31 \mathrm{ft}$, roadway width: $13 \mathrm{ft}$. On the left bank upstream are large trees, a gravel road, a house, and a lawn high on the overbank. On the right bank upstream are small trees on a steep bank, VT 12 parallels the right bank and is within two bridge lengths, the road embankment is grass. On the left bank downstream are some large trees, but mostly small trees about $80 \mathrm{ft}$ high. The right bank downstream surface cover is equivalent to that on the right bank upstream. The right road approach is unpaved for about $20 \mathrm{ft}$ until in intersects VT12. There has been a failure of the left bank upstream wingwall.

\section{Upstream Channel Assessment}

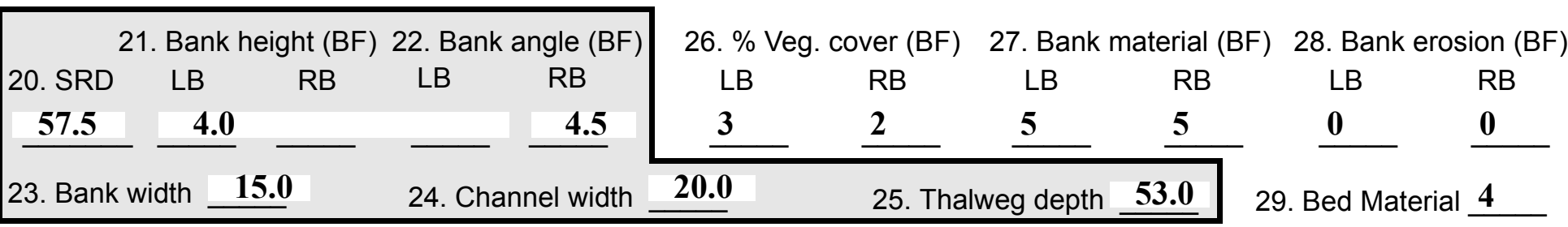

30 .Bank protection type:

LB 2

RB 2

31. Bank protection condition: LB 2

RB 2

SRD - Section ref. dist. to US face \% Vegetation (Veg) cover: 1- 0 to 25\%; 2- 26 to 50\%; 3- 51 to $75 \%$; 4- 76 to $100 \%$

Bed and bank Material: 0- organics; 1- silt / clay, <1/16mm; 2- sand, 1/16 - 2mm; 3- gravel, 2 - 64mm;

4- cobble, 64 - 256mm; 5- boulder, > 256mm; 6- bedrock; 7- manmade

Bank Erosion: 0- not evident; 1- light fluvial; 2- moderate fluvial; 3- heavy fluvial / mass wasting

Bank protection types: 0- absent; 1- < 12 inches; 2- < 36 inches; 3- < 48 inches; 4- < 60 inches; 5- wall / artificial levee

Bank protection conditions: 1- good; 2- slumped; 3- eroded; 4- failed

32. Comments (bank material variation, minor inflows, protection extent, etc.):

There are small and large trees on the left bank upstream except near the bridge which is shrubland. There are small trees on the right bank upstream. The left bank material is boulder, cobble and gravel, with some surficial sand. The right bank material is boulder, cobble, and gravel. The bed material is mainly cobble with some gravel and boulder. There is an old drywall on the left bank at bank full level from the upstream left wingwall to $80 \mathrm{ft}$ high. The wall is up to $5 \mathrm{ft}$ high but is slumped to the extent that here it is counted only as class 2 protection. There is also a drywall on the right bank upstream $92 \mathrm{ft}$ upstream to about $200 \mathrm{ft}$ upstream, and is up to $10 \mathrm{ft}$ high. There does not appear to be an impact zone in this area, it may have been built to stabilize the VT 12 embankment. There is also boulder protection on the right bank 20 to $50 \mathrm{ft}$ upstream. 
33.Point/Side bar present? $\mathbf{N}(Y$ or $N$. if $N$ type ctrl-n pb)34. Mid-bar distance: -

35. Mid-bar width: -

36. Point bar extent: feet (US, UB) to feet (US, UB, DS) positioned $\%$ LB to $\% \mathrm{RB}$

37. Material: -

38. Point or side bar comments (Circle Point or Side; Note additional bars, material variation, status, etc.):

NO POINT BARS

39. Is a cut-bank present? $\underline{\mathbf{N}}$ (Y or if $\mathrm{N}$ type ctrl-n cb)

40. Where? - $\quad$ (LB or RB)

41. Mid-bank distance: -

42. Cut bank extent: feet (US, UB) to feet (US, UB, DS)

43. Bank damage: (1- eroded and/or creep; 2- slip failure; 3- block failure)

44. Cut bank comments (eg. additional cut banks, protection condition, etc.):

\section{Is channel scour present? $\mathbf{N}$ ( $Y$ or if $N$ type ctrl-n cs)}

47. Scour dimensions: Length Width Depth : 46. Mid-scour distance: -

48. Scour comments (eg. additional scour areas, local scouring process, etc.):

NO CHANNEL SCOUR

\section{Are there major confluences? $\mathbf{N}$}

51. Confluence 1: Distance Confluence 2: Distance 52. Enters on Enters on 4. Confluence comments (eg. confluence name):

\section{NO MAJOR CONFLUENCES}

50. How many? -

53. Type(1- perennial; 2- ephemeral)

Type (1-perennial; 2-ephemeral)

\section{Under Bridge Channel Assessment}

55. Channel restraint (BF)? LB 2

\begin{tabular}{|ccccc}
\hline \multicolumn{2}{|c}{ 56. Height (BF) } & \multicolumn{3}{c}{57 Angle (BF) } \\
LB & RB & LB & RB \\
$\mathbf{3 0 . 0}$ & & & $\mathbf{1 . 0}$ & \\
\hline
\end{tabular}
(1- natural bank; 2- abutment; 3- artificial levee)

58. Bank width (BF) 59. Channel width (Amb) -

61. Material (BF)

LB RB

$\underline{2} \quad \underline{7}$
62. Erosion (BF)

LB RB

$7 \quad 0$

Bed and bank Material: 0- organics; 1- silt / clay, < 1/16mm; 2- sand, 1/16 - 2mm; 3- gravel, 2 - 64mm; 4- cobble, 64 - 256mm; 5- boulder, > 256mm; 6- bedrock; 7- manmade

Bank Erosion: 0- not evident; 1- light fluvial; 2- moderate fluvial; 3- heavy fluvial / mass wasting

64. Comments (bank material variation, minor inflows, protection extent, etc.):

4

The under bridge bed material is mostly cobble with gravel and sand, occasional boulder. The upstream reach has more boulders than under bridge, but the D50 is probably in the cobble range for them both. 
65. Debris and Ice Is there debris accumulation?

67. Debris Potential (1- Low; 2- Moderate; 3- High)

69. Is there evidence of ice build-up? $\underline{1}(Y$ or $N)$

70. Debris and Ice Comments:

1

There are no trees falling into the channel, the deck is fairly high, the bank full constriction under the bridge is not too great. Paraphrased from a resident: ice flow is in small pieces with no blockage upstream, most ice forms in the pool downstream.

\begin{tabular}{|l|c|c|c|c|c|c|c|c|}
\hline Abutments & $\begin{array}{c}\text { 71. Attack } \\
\angle \text { (BF) }\end{array}$ & $\begin{array}{c}\text { 72. Slope } \angle \\
\text { (Qmax) }\end{array}$ & $\begin{array}{c}\text { 73. Toe } \\
\text { loc. (BF) }\end{array}$ & $\begin{array}{c}\text { 74. Scour } \\
\text { Condition }\end{array}$ & $\begin{array}{c}75 . \text { Scour } \\
\text { depth }\end{array}$ & $\begin{array}{c}\text { 76. Exposure } \\
\text { depth }\end{array}$ & 77. Material & 78. Length \\
\hline LABUT & & $\mathbf{0}$ & $\mathbf{9 0}$ & $\mathbf{2}$ & $\mathbf{0}$ & - & - & $\mathbf{9 0 . 0}$ \\
\hline RABUT & $\mathbf{4}$ & $\mathbf{0}$ & $\mathbf{9 0}$ & & & $\mathbf{2}$ & $\mathbf{1}$ & $\mathbf{2 9 . 5}$ \\
\hline
\end{tabular}

Pushed: $L B$ or RB

Toe Location (Loc.): 0- even, 1- set back, 2- protrudes

Scour cond.: 0- not evident; 1- evident (comment); 2- footing exposed; 3-undermined footing; 4- piling exposed; 5- settled; 6- failed

Materials: 1- Concrete; 2- Stone masonry or drywall; 3- steel or metal; 4- wood

79. Abutment comments (eg. undermined penetration, unusual scour processes, debris, etc.):

1

0

4

There is a free-poured concrete footing on the right abutment which is undermined by a maximum of $1.8 \mathrm{ft}$, however the abutment continues deeper than this and does not seem to be undermined. Under the junction of the upstream right wingwall and the right abutment there may be some undermining, the rangepole strikes wood but it is set back $0.5 \mathrm{ft}$. The abutments and wingwalls are stone filled log cribwork. Some logs of the right abutment under the deck are crushed. Some logs of both abutments appear to be rotting. See photos 11 and 12. The water is 2 feet deep at the junction of the upstream right wingwall and right abutment, and the average thalweg depth upstream and downstream was about $1 \mathrm{ft}$, so scour depth was estimated at $1 \mathrm{ft}$.

80. Wingwalls:

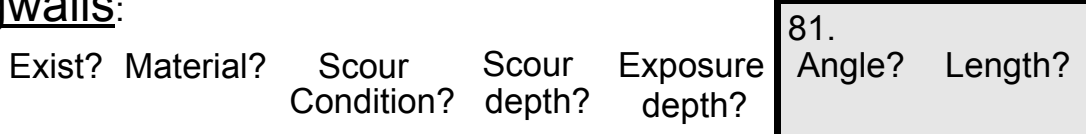

USLWW:

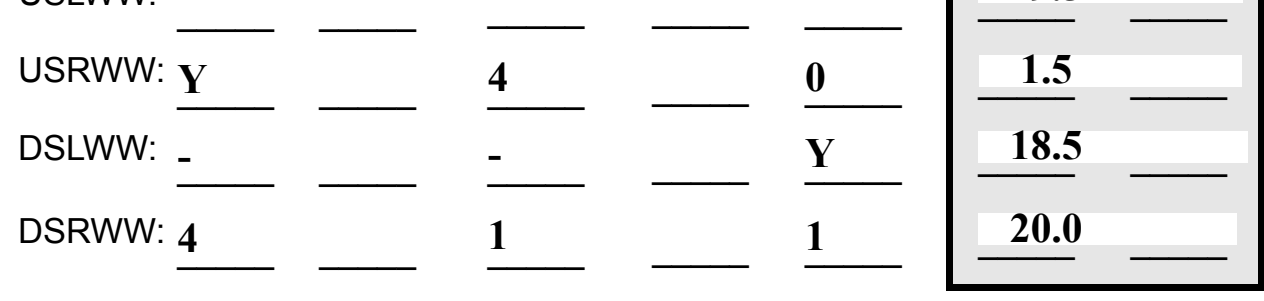

Wingwall materials: 1- Concrete; 2- Stone masonry or drywall; 3- steel or metal; 4- wood

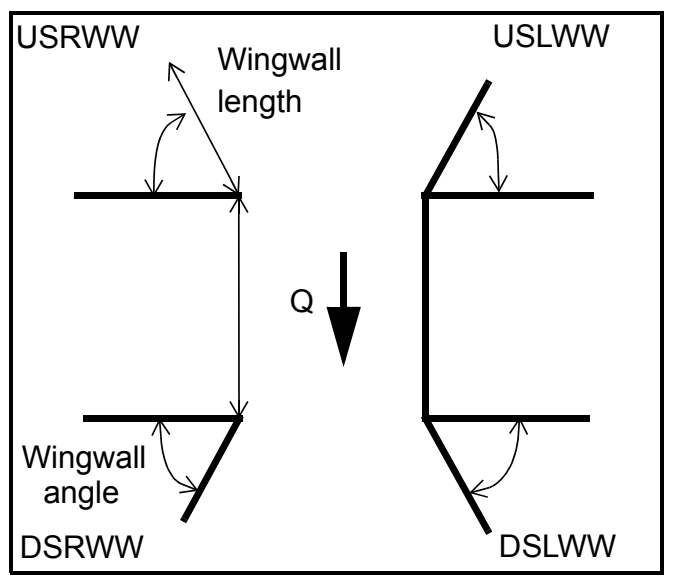

82. Bank / Bridge Protection:

\begin{tabular}{|l|l|l|l|l|l|l|c|c|}
\hline Location & USLWW & USRWW & LABUT & RABUT & LB & RB & DSLWW & DSRWW \\
\hline Type & $\mathbf{0}$ & $\mathbf{0}$ & $\mathbf{Y}$ & - & $\mathbf{1}$ & $\mathbf{1}$ & - & - \\
\hline Condition & $\mathbf{Y}$ & - & $\mathbf{4}$ & - & $\mathbf{1}$ & $\mathbf{2}$ & - & - \\
\hline Extent & $\mathbf{4}$ & - & $\mathbf{0}$ & $\mathbf{2}$ & $\mathbf{3}$ & $\mathbf{0}$ & $\mathbf{0}$ & - \\
\hline
\end{tabular}

Bank / Bridge protection types: 0- absent; 1- < 12 inches; 2- < 36 inches; 3- < 48 inches; 4- < 60 inches; 
83. Wingwall and protection comments (eg. undermined penetration, unusual scour processes, etc.):

-
-
-
-
-
2
1
4
3
1
1

\section{Piers:}

84. Are there piers? Th (Y or if $N$ type ctrl-n pr)

\begin{tabular}{|l|l|l|l|l|l|l|l|}
\hline \multirow{2}{*}{$\begin{array}{l}85 . \\
\text { Pier no. }\end{array}$} & \multicolumn{3}{|c|}{ width (w) feet } & \multicolumn{5}{c|}{ elevation (e) feet } \\
\cline { 2 - 8 } & w1 & w2 & w3 & e@w1 & e@w2 & e@w3 \\
\hline Pier 1 & & & & $\mathbf{5 5 . 0}$ & $\mathbf{1 7 . 5}$ & $\mathbf{5 5 . 0}$ \\
\hline Pier 2 & & & & $\mathbf{1 9 . 0}$ & $\mathbf{3 0 . 0}$ & $\mathbf{2 4 . 0}$ \\
\hline Pier 3 & & & - & $\mathbf{3 0 . 0}$ & $\mathbf{2 1 . 0}$ & - \\
\hline Pier 4 & - & - & - & - & - & - \\
\hline
\end{tabular}

\begin{tabular}{|l|l|l|l|l|}
\hline Level 1 Pier Descr. & \multicolumn{1}{|c|}{1} & \multicolumn{1}{|c|}{2} & \multicolumn{1}{|c|}{3} & \multicolumn{1}{|c|}{} \\
\hline 86. Location (BF) & ere is & altho & pro- & dow \\
\hline 87. Type & good & ugh & tec- & nstre \\
\hline 88. Material & cov- & there & tion. & am \\
\hline 89. Shape & erag & may & Ther & left \\
\hline 90. Inclined? & e at & have & e is & wing \\
\hline 91. Attack $\angle$ (BF) & the & been & spar & wall, \\
\hline 92. Pushed & dow & some & se & there \\
\hline 93. Length (feet) & - & - & - & - \\
\hline 94. \# of piles & nstre & unde & pro- & is \\
\hline 95. Cross-members & am & rmin & tec- & more \\
\hline 96. Scour Condition & right & ing & tion & rip \\
\hline 97. Scour depth & wing & of & at & rap \\
\hline 98. Exposure depth & wall & the & the & at \\
\hline
\end{tabular}

LFP, LTB, LB, MCL, MCM, MCR, RB, RTB, RFP

1- Solid pier, 2-column, 3- bent

1-Wood; 2- concrete; 3- metal; 4- stone

1- Round; 2- Square; 3- Pointed

Y-yes; $N$ - no

$L B$ or $R B$

0- none; 1- laterals; 2- diagonals; 3- both

0- not evident; 1- evident (comment);

2- footing exposed; 3- piling exposed;

4- undermined footing; 5- settled; 6- failed 
99. Pier comments (eg. undermined penetration, protection and protection extent, unusual scour processes, etc.):

the end of the wingwall to prevent road wash. There are two large probably naturally placed boulders in the channel near the left abutment. The upstream left wingwall has failed.

$\mathbf{N}$

100.

\section{E. Downstream Channel Assessment}

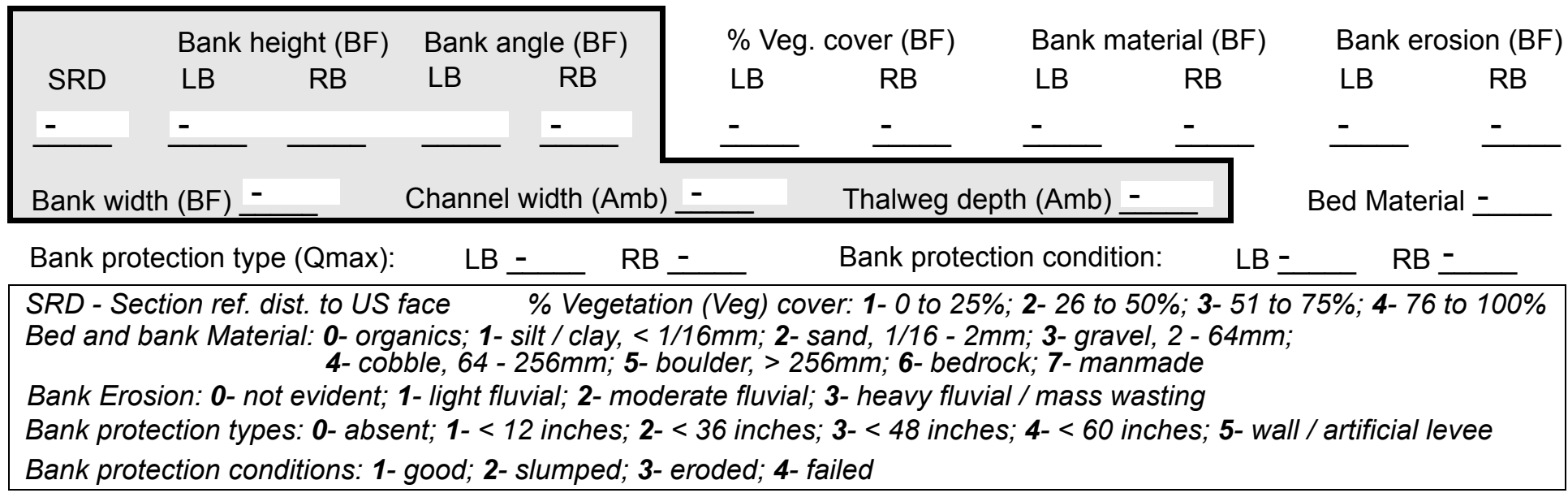

Comments (eg. bank material variation, minor inflows, protection extent, etc.):

$-$

-

-

-

-

-

-

-

-

$-$

-

$-$

\section{Is a drop structure present? _ ( $Y$ or $N$, if $N$ type ctrl-n ds) 102. Distance: _ _ feet}
103. Drop: - feet
104. Structure material:
(1- steel sheet pile; 2- wood pile; 3- concrete; 4- other)

105. Drop structure comments (eg. downstream scour depth):

-

$-$

$-$

- 
106. Point/Side bar present? (Y or $N$. if $N$ type ctrl-n pb)Mid-bar distance:

Mid-bar width: -

Point bar extent: feet -

(US, UB, DS) to feet (US, UB, DS) positioned $\%$ LB to $\% R B$ Material:

Point or side bar comments (Circle Point or Side; note additional bars, material variation, status, etc.):

S a cut-bank present? $\mathbf{N}$ (Y or if $N$ type ctrl-n cb) Where? $\underline{\mathbf{O}}$ (LB or RB) Mid-bank distance: PIE Cut bank extent: $\underline{\mathbf{R S}}$ feet ___ (US, UB, DS) to feet __ (US, UB, DS)

Bank damage: (1- eroded and/or creep; 2- slip failure; 3- block failure)

Cut bank comments (eg. additional cut banks, protection condition, etc.):

Is channel scour present? Scour dimensions: Length $\underline{2}$ Width 2 ( $Y$ or if $N$ type ctrl- $n c s)$ Depth: 2 Mid-scour distance: $\underline{3}$

Scour comments (eg. additional scour areas, local scouring process, etc.):

3

0

2

Are there major confluences? 1 ( 1 or if $N$ type ctrl-n $m c)$

Confluence 1: Distance the Enters on ban ( $L B$ or RB)

Confluence 2: Distance surfiEnters on $\underline{\text { cial }}$ (LB or RB)

Positioned $\mathbf{0}$ $\%$ LB to $\underline{0}$ $\%$ RB Confluence comments (eg. confluence name):

$\mathrm{d}$ is at least $0.5 \mathrm{ft}$ deep, but deeper material is probably analogous to the bed material, which is gravel cobble and sand. There is sparse native protection on the right bank along the right edge of water. There is intermit-

\section{F. Geomorphic Channel Assessment}

107. Stage of reach evolution ten
1- Constructed

2- Stable

3- Aggraded

4- Degraded

5- Laterally unstable

6- Vertically and laterally unstable 
108. Evolution comments (Channel evolution not considering bridge effects; See HEC-20, Figure 1 for geomorphic descriptors):

$\mathrm{t}$ inflow from a $1.5 \mathrm{ft}$ diameter culvert on the right bank downstream $30 \mathrm{ft}$ from the bridge. 


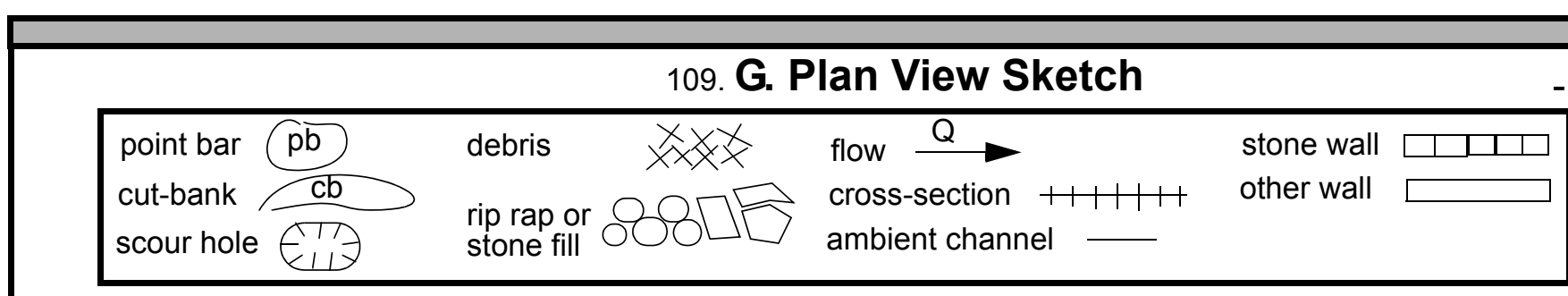


APPENDIX F:

SCOUR COMPUTATIONS 
SCOUR ANALYSIS

$\begin{array}{lll}\begin{array}{l}\text { Structure Number: } \\ \text { Road Number: }\end{array} & \begin{array}{l}\text { TH } 80 \\ \text { Locust Creek }\end{array} & \begin{array}{l}\text { Town: County: Windsor } \\ \text { Stream: }\end{array} \\ & \text { Date: 11/20/95 } & \text { Checked: }\end{array}$

Analysis of contraction scour, live-bed or clear water?

Neills Equation

$\mathrm{VC}=11.52 * \mathrm{Y} 1 \wedge 0.1667 * \mathrm{D} 50 \wedge 0.33$ with $\mathrm{Ss}=2.65$

(Richardson and others, 1993, p. 31, eq. 14)

Approach section

Characteristic

Total discharge, cfs

Main Channel Area, ft2

Left overbank area, ft2

Right overbank area, ft2

Top width main channel, ft

Top width L overbank, ft

Top width $\mathrm{R}$ overbank, ft

D50 of channel, ft

D50 left overbank, ft

D50 right overbank, ft

\begin{tabular}{lll}
$100 \mathrm{Yr}$ & $500 \mathrm{Yr}$ & other Q \\
4000 & 5100 & 4800 \\
818 & 1196 & 966 \\
0 & 0 & 0 \\
0 & 0 & 0 \\
89.2 & 102.6 & 92.6 \\
0 & 0 & 0 \\
0 & 0 & 0 \\
0.336 & 0.336 & 0.336 \\
0 & 0 & 0 \\
0 & 0 & 0 \\
& & \\
$\quad 9.2$ & \multicolumn{1}{c}{11.7} & \multicolumn{1}{c}{10.4} \\
ERR & ERR & ERR \\
ERR & ERR & ERR \\
84892 & 144079 & 108492 \\
84892 & 144079 & 108492 \\
0 & 0 & 0 \\
0 & 0 & 0 \\
0 & 0 & 0 \\
4000 & 5100 & 4800 \\
0 & 0 & 0 \\
0 & 0 & 0
\end{tabular}

$\mathrm{Vm}$, mean velocity $\mathrm{MC}$, $\mathrm{ft} / \mathrm{s}$

Vl, mean velocity, LOB, ft/s

Vr, mean velocity, ROB, ft/s

Vc-m, crit. velocity, MC, ft/s

$\mathrm{VC}-1$, crit. velocity, LOB, ft/s

$\begin{array}{lll}4.9 & 4.3 & 5.0\end{array}$

ERR ERR ERR

ERR ERR ERR

Vc-r, crit. velocity, ROB, ft/s

$\mathrm{N} / \mathrm{A}$

12.1

N/A N/A N

Results

Live-bed(1) or Clear-Water(0) Contraction Scour? Main Channel

Left Overbank

$0 \quad 0 \quad 0$

Right Overbank

$\begin{array}{lll}\mathrm{N} / \mathrm{A} & \mathrm{N} / \mathrm{A} & \mathrm{N} / \mathrm{A}\end{array}$

N/A N/A N/A


Clear Water Contraction Scour in MAIN CHANNEL

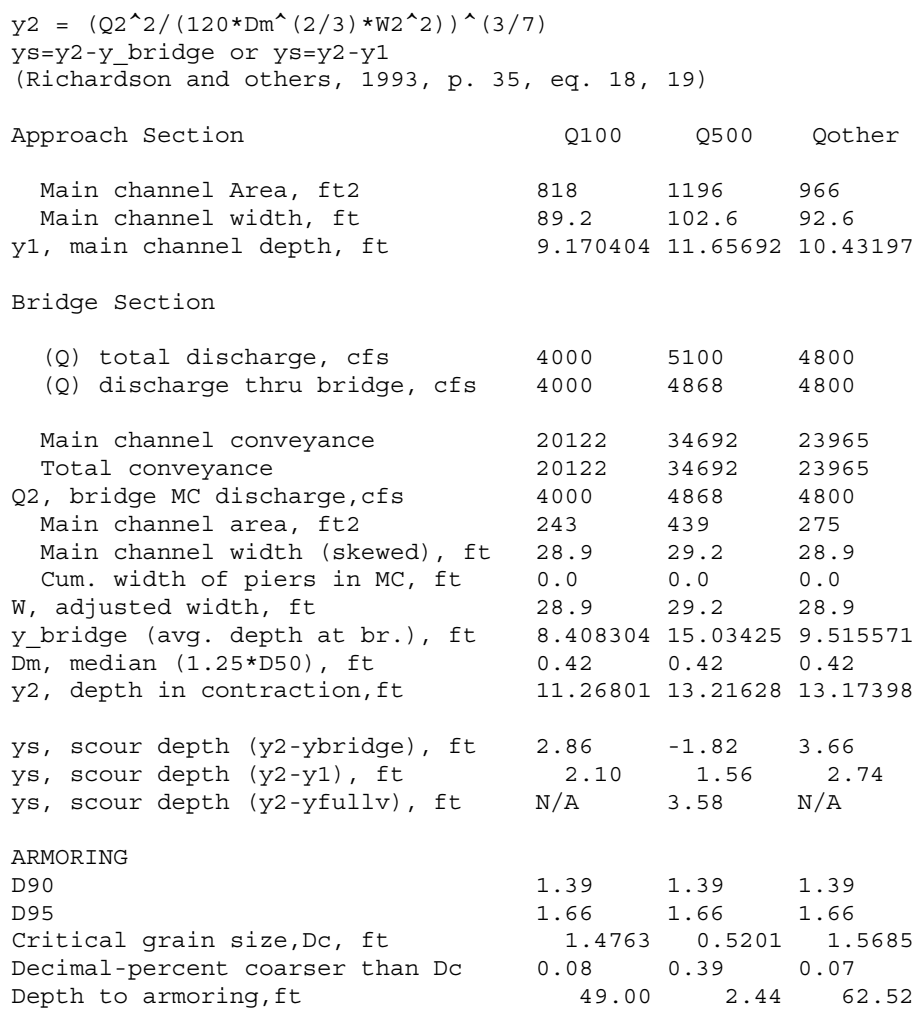

Pressure Flow Scour (contraction scour for orifice flow conditions)

\begin{tabular}{|c|c|c|c|}
\hline $\mathrm{Hb}+\mathrm{Ys}=\mathrm{Cq} * \mathrm{qbr} / \mathrm{Vc}$ & $C f=1$ & $\Upsilon^{\wedge} 0.43 \quad<$ & $=1$ ) \\
\hline $\begin{array}{l}\text { Chang Equation CC=SQRT }[0.10 *( \\
\text { (Richardson and others, 1995, p. } 14\end{array}$ & $\begin{array}{l}(y-w) \\
\text { 6) }\end{array}$ & 6) ] +0.79 & $(<=1)$ \\
\hline & Q100 & Q500 & OtherQ \\
\hline Q thru bridge main chan, cfs & 0 & 4868 & 0 \\
\hline Vc, critical velocity, ft/s & 0 & 12.1 & 0 \\
\hline Vc, critical velocity, $\mathrm{m} / \mathrm{s}$ & 0 & 3.6879 & 0 \\
\hline Main channel width (skewed), ft & 0 & 29.2 & 0 \\
\hline Cum. width of piers, ft & 0 & 0 & 0 \\
\hline w, adjusted width, ft & 0 & 29.2 & 0 \\
\hline qbr, unit discharge, $f t^{\wedge} 2 / \mathrm{s}$ & ERR & 166.7123 & ERR \\
\hline qbr, unit discharge, $\mathrm{m}^{\wedge} 2 / \mathrm{s}$ & $\mathrm{N} / \mathrm{A}$ & 15.48657 & $\mathrm{~N} / \mathrm{A}$ \\
\hline Area of full opening, $\mathrm{ft}^{\wedge} 2$ & 0 & 439 & 0 \\
\hline $\mathrm{Hb}$, depth of full opening, ft & ERR & 15.03425 & ERR \\
\hline $\mathrm{Hb}$, depth of full opening, m & $\mathrm{N} / \mathrm{A}$ & 4.582215 & $\mathrm{~N} / \mathrm{A}$ \\
\hline Fr, Froude number MC & 1 & 0.5 & 1 \\
\hline Cf, Fr correction factor $(<=1.0)$ & 1.5 & 1 & 1.5 \\
\hline Elevation of Low Steel, ft & 0 & 496.617 & 0 \\
\hline Elevation of Bed, $\mathrm{ft}$ & $\mathrm{N} / \mathrm{A}$ & 481.5828 & $\mathrm{~N} / \mathrm{A}$ \\
\hline Elevation of approach WS, ft & 0 & 499.33 & 0 \\
\hline $\mathrm{HF}$, bridge to approach, ft & 0 & 0.15 & 0 \\
\hline Elevation of WS immediately US, ft & 0 & 499.18 & 0 \\
\hline ya, depth immediately US, ft & $\mathrm{N} / \mathrm{A}$ & 17.59725 & $\mathrm{~N} / \mathrm{A}$ \\
\hline ya, depth immediately us, m & $\mathrm{N} / \mathrm{A}$ & 5.46838 & $\mathrm{~N} / \mathrm{A}$ \\
\hline Mean elev. of deck, ft & 0 & 498.163 & 0 \\
\hline w, depth of overflow, ft $(>=0)$ & 0 & 1.017 & 0 \\
\hline Cc, vert contrac correction $(<=1.0)$ & ERR & 0.976214 & ERR \\
\hline Ys, depth of scour (chang), ft & $\mathrm{N} / \mathrm{A}$ & -0.92066 & $\mathrm{~N} / \mathrm{A}$ \\
\hline
\end{tabular}




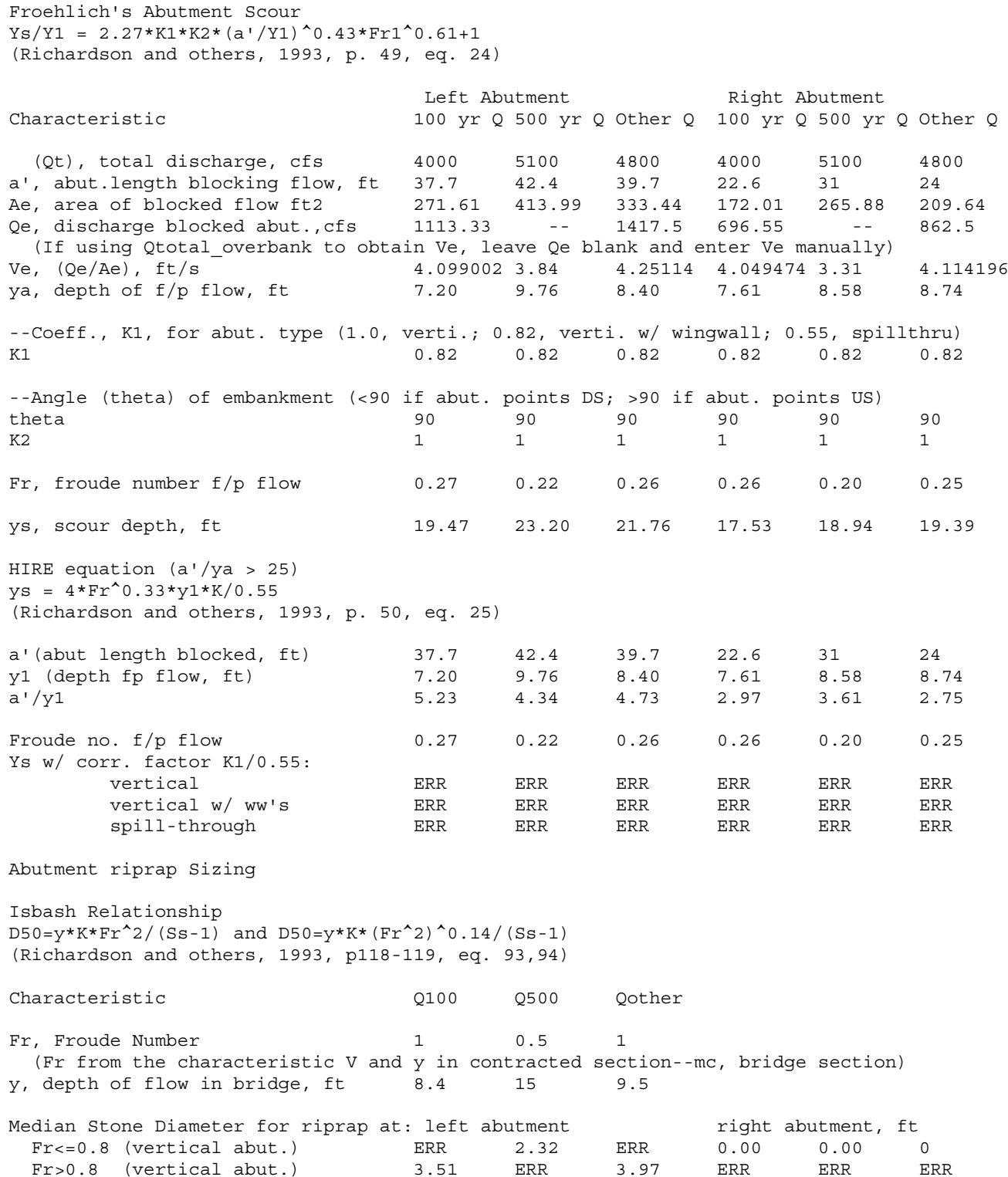

Abutment riprap sizing

Isbash Relationship

$\mathrm{D} 50=\mathrm{y} * \mathrm{~K} * \mathrm{Fr}^{\wedge} 2 /(\mathrm{SS}-1)$ and $\mathrm{D} 50=\mathrm{y} * \mathrm{~K} *(\mathrm{Fr} \wedge 2)^{\wedge} 0.14 /(\mathrm{SS}-1)$

(Richardson and others, 1993, p118-119, eq. 93,94)

$\begin{array}{lll}\text { Characteristic } & \text { Q100 Q500 Qother }\end{array}$

Fr, Froude Number $\quad 1 \quad 0.5 \quad 1$ (Fr from the characteristic $\mathrm{V}$ and $\mathrm{y}$ in contracted section--mc, bridge section) 